\title{
Quartz arenites and laterites in the Moesian Group (Upper Triassic), northwestern Bulgaria: possible evidence for the effect of the Carnian Humid Episode
}

\author{
Athanas Chatalov \\ Sofia University "St Kliment Ohridski”, 15 Tsar Osvoboditel Blvd, 1504 Sofia, Bulgaria; e-mail: chatalov@gea.uni-sofia.bg \\ (Accepted in revised form: July 2017)
}

\begin{abstract}
Quartz-rich sandstones and ironstone crusts occur in the lowermost part of the Upper Triassic Moesian Group exposed in the western Balkanides. On the basis of performed field studies, micropetrography, X-ray diffraction, and major-element chemistry, these deposits are defined as first-cycle quartz arenites and laterites, respectively. The former were deposited in an alluvial environment, while the latter developed in gravel-dominated fluvial sediments. The main control on their formation was warm to hot humid climate conditions combined with low relief, quiescent tectonic setting, mixed source area, and slow sedimentation rate. The decreasing compositional maturity of the sandstones forming the Glavatsi Member (quartz arenites $\rightarrow$ feldsarenites $\rightarrow$ litharenites), the disappearance of the lateritic crusts upwards in the continental succession, and the presence of thick overlying fluvial and playa deposits in the Komshtitsa Formation (or Chelyustnitsa Formation) reflect gradual transition from humid to subhumid climate, and then to persistent semi-arid climate regime. This irreversible trend correlates with other Upper Triassic strata deposited in the Western Tethys realm and adjacent areas. The coeval formation of quartz arenites and laterites must have been related to the most distinctive climate change during the Triassic, i.e., the global Carnian Humid Episode. The new results and interpretations appear to be the first geological record for the effect of pronounced mid-Carnian humidity reported from Eastern Europe. They also present indirect sedimentological evidence for the stratigraphical range of the Moesian Group in NW Bulgaria.
\end{abstract}

Chatalov, A. 2017. Quartz arenites and laterites in the Moesian Group (Upper Triassic), northwestern Bulgaria: possible evidence for the effect of the Carnian Humid Episode. Geologica Balcanica 46 (1), 3-25.

Keywords: first-cycle quartz arenite, laterite, tropical humid climate, Carnian Humid Episode, Moesian Group, western Balkanides.

\section{INTRODUCTION}

Lithological and mineralogical proxies for humid palaeoclimate conditions (both temperate and tropical) include coal, lignite, peat, laterite, bauxite, kaolinite, halloysite, karst, ironstone (Sellwood and Price, 1993; Parrish, 1998; Gornitz, 2009; Boucot et al., 2013), siderite (Ludvigson et al., 2013), oil shale (Quan et al., 2014), and even amber (Gianolla et al., 1998). Siliciclastic influx to marine and lacustrine carbonate environments is also a well-recognised indicator of terrestrial humidity (Flügel, 2004). First-cycle quartz arenites are usually considered as depositional products of warm to hot humid climate (Suttner et al., 1981; Johnsson et al., 1988; Avigad et al., 2005; Van de Kamp, 2010; Garzanti et al., 2013; Roy and Roser, 2013), but a controversy may arise in such interpretation if recycled or diagenetic origin of the sandstones cannot be explicitly ruled out (Dott, 2003).

This study reports the presence of first-cycle quartz arenites and lateritic crusts in the lowermost part of the Upper Triassic Moesian Group, which is exposed in northwestern Bulgaria. On the basis of petrographic, mineralogical, and geochemical data, it is suggested that these deposits were formed mainly as a result of tropical humid climatic conditions. The latter indicate the possible effect of a distinctive climate perturbation in the late early Carnian, which has been documented from many regions around the globe and is known under different names, e.g., Carnian Humid 
Episode (Ruffel et al., 2016). The new results and interpretations appear to be the first geological record of a pronounced mid-Carnian climate pluvialisation from Eastern Europe. They also present indirect sedimentological evidence for the age of the basal deposits of the Moesian Group in the western Balkanides.

\section{GEOLOGICAL FRAMEWORK}

The Triassic sedimentary rocks exposed in northwestern Bulgaria are assigned to the Balkanide (facies) type of Triassic (Ganev, 1974; Chatalov, 1980). Geographically, outcrops of the Upper Triassic Moesian Group (Chemberski et al., 1974) are located in the western sectors of the Fore-Balkan region and Stara Planina Mountains. According to the Alpine tectonic subdivision of Bulgaria proposed by Ivanov (1998), these exposures occur in the West Balkan Zone of the External Balkanides (Berkovitsa, Vratsa, and Montana units) and the northern part of the Western Srednogorie Zone of the Intermediate Balkanides (Vidlich thrust sheet). Continental deposits of the Moesian Group have unconformable boundaries with underlying marine strata of the Iskar Carbonate Group (Lower-Middle Triassic) and overlying Lower or Middle Jurassic sedimentary rocks (Goranov, 1961; Tronkov, 1963, 1973; Tronkov et al., 1965). The total thickness of the unit varies from about $20 \mathrm{~m}$ (Tronkov, 1960; Goranov, 1961) to more than 250-300 m (Tronkov et al., 1965; Tronkov, 1995b; Zagorchev and Budurov, 2007). Although designated originally as "Rhaetian" (Tronkov, 1960, 1963; Goranov, 1961; Gnoevaya, 1965; Tronkov et al., 1965), the rocks of the Moesian Group have presumably Carnian-Norian stratigraphical range, as defined by their stratigraphic position and biostratigraphic data from the underlying carbonate deposits (Tronkov, 1969, 1973). The Moesian Group comprises the uppermost regressive part of a secondorder transgressive-regressive (T-R) stratigraphic cycle (in the sense of Duval et al., 1998) in the Triassic System of the western Balkanides (Chatalov, 2013).

\section{HISTORY OF RESEARCH}

Macroscopic characteristics (rock colour, lithology, structures, and textures) of siliciclastic and carbonate deposits of the Moesian Group outcropping in NW Bulgaria were described by several authors (Tronkov, 1960, 1995a, b; Goranov, 1961; Gnoevaya, 1965; Tronkov et al., 1965; Mader and Chatalov, 1992; Zagorchev and Budurov, 2007; Ajdanlijsky, 2008a, b), while micropetrographic and mineralogical studies were performed by Goranov (1961) and Gnoevaya (1965). Various lithofacies types and lithogenetic associations (Mader and Chatalov, 1992), or sedimentary facies types and associations (Zagorchev and Budurov, 2007), were distinguished and interpreted as products of continental, marginal-marine and shallow marine depositional environments (Vaptsarova et al., 1984; Mader and Chatalov, 1992; Zagorchev and Budurov, 2007). Arid and semi-arid climatic conditions were suggested by Goranov (1961) and Mader and Chatalov (1992), respectively. A syntectonic pattern of sedimentation related to the early Cimmerian phase was emphasised by Tronkov (1963). Three formal units of lower rank (Komshtitsa Formation, Glavatsi Formation, Chelyustnitsa Formation) were established in exposures of the Moesian Group by Tronkov (1969), Tronkov and Monov (1971), and Zagorchev and Budurov (2007). The Glavatsi Formation has its holostratotype in the homonymous well R-29 (Tronkov and Monov, 1971), but later a rank of member of the Komshtitsa Formation was proposed by Chemberski and Vaptsarova (1979). The lithology of this unit, which comprises in many places the lowermost part of the Moesian Group, is represented by non-calcareous, mostly quartzose sandstones, locally containing gravel-sized extraclasts. The member grades upwards or laterally into the Komshtitsa Formation, commonly by an increase in the amount of carbonate matrix and/or clasts. According to Zagorchev and Budurov (2007), the Glavatsi Member should be considered as part of the gravel-dominated Chelyustnitsa Formation because of the close areal and genetic relationships between these units. In a comprehensive synopsis, Mader and Chatalov (1992) used the term "Keuper-facies" instead of "Moesian Group" and made correlations with similar Keuper facies from some countries in Europe and other areas in southwestern and central Bulgaria.

\section{MATERIAL AND METHODS}

Five stratigraphic sections (Chelyustnitsa, Melyane, Komshtitsa, Ravna, Brakyovtsi) and six additional outcrops (Belimel, Gaganitsa, Kostentsi, Krivi Potok, Klokotish, Gintsi) of the Glavatsi Member were studied in the field (Fig. 1). The thicknesses, boundaries, stratification pattern, colour, structures, and textures of the siliciclastic rocks were described. The lowermost part of the Moesian Group (Komshtitsa Formation or Chelyustnitsa Formation) was also studied in other four outcrops (Druzhevo, Milanovo, Sfrazhen, Zgorigrad), with special emphasis on the occurrence of ferruginous crusts. Twenty-seven samples were collected from sandstones and iron-rich crusts for preparation of standard thin-sections and observation on transmitting light-microscope. The grain sorting, roundness, and sphericity were determined by using the comparison charts of Longiaru (1987), Pettijohn (1975) and Powers (1953), respectively. Framework mineral composition of the sandstones was quantified by traditional point counting of minimum 300 detrital grains in each thin-section. The following grain type categories were distinguished: Qt (total quartz), Qm (monocrystalline quartz), Qp (polycrystalline quartz), F (feldspar), Lt (total lithic fragments), Ls (sedimen- 


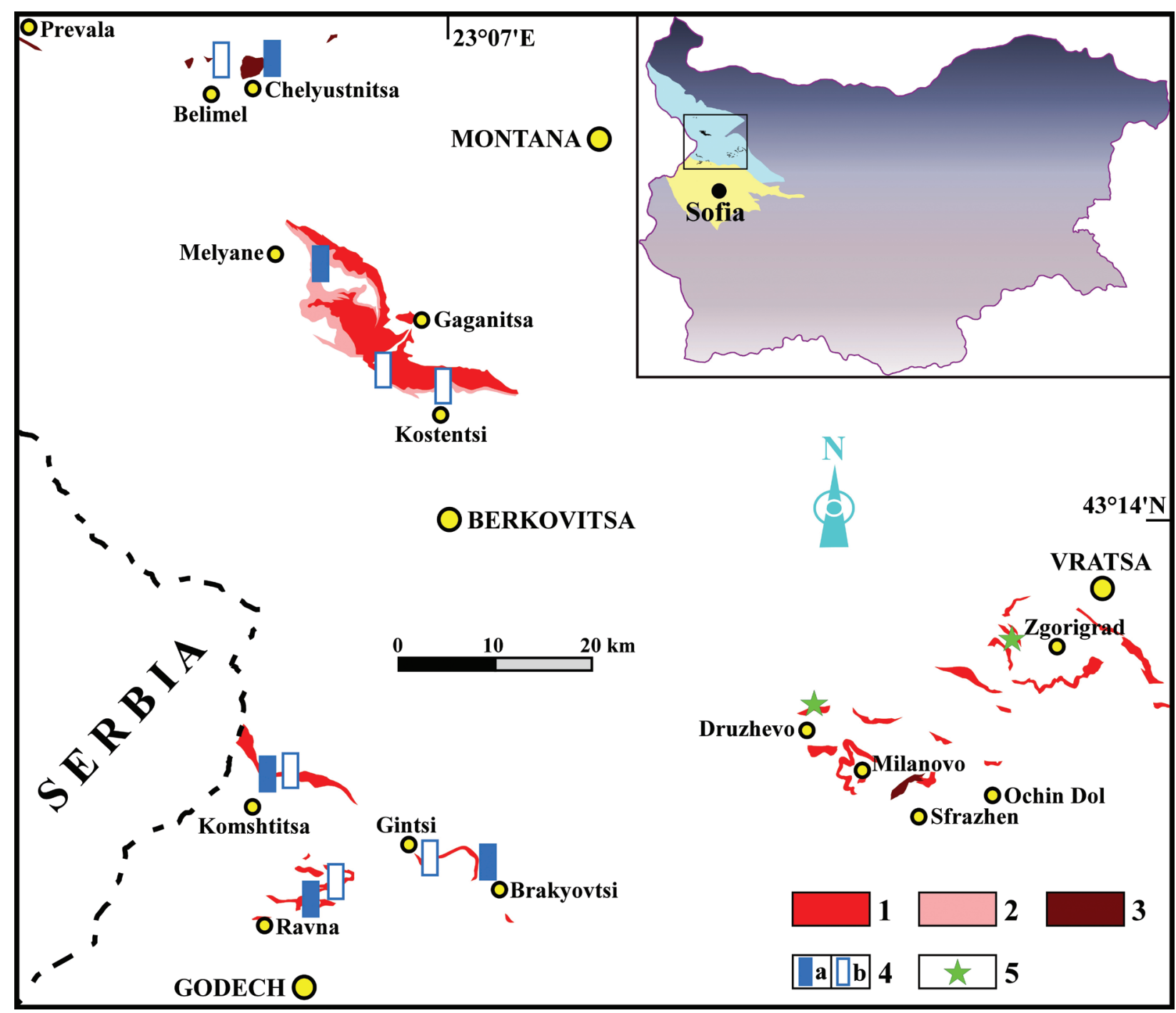

Fig. 1. Location map with exposures of the Moesian Group (data used from Angelov et al., 2007, 2008a, b, 2009a, b; Zagorchev and Budurov, 2007). Legend: 1 - Komshtitsa Formation, 2 - Glavatsi Member, 3 - Chelyustnitsa Formation, 4 - studied sections $(a)$ and outcrops $(b)$ of the Glavatsi Member, 5 - outcrops with lateritic crusts. Inset map: blue - West Balkan Zone, yellow - western part of the Srednogorie Zone. The Alpine tectonic subdivision is after Ivanov (1998).

tary rock fragments, including chert), and Lp (plutonic lithic fragments). The ternary discrimination diagram proposed by Folk et al. (1970) was used for petrographic classification of the sandstones. The majorelement chemistry of ten powdered samples from quartz-rich sandstones was determined by means of wet chemical analysis. Analytical data for the sandstone compositions were plotted in the classification diagrams of Pettijohn et al. (1972) and Herron (1988). The mineralogy of the ferruginous crusts was determined by X-ray diffraction of four powdered samples with a TUR M62 diffractometer, using filtered $\mathrm{Co} \mathrm{K \alpha}$ radiation in the $4-80^{\circ} 2 \theta$ range, step size $0.02^{\circ}$. The samples were prepared selectively from the matrix of the crusts after carefully removing the associated carbonate clasts.

\section{QUARTZ-RICH SANDSTONES AND LATERITES - DESCRIPTION}

Occurrence, vertical distribution, and macroscopic characteristics

In most of the studied sections, the Glavatsi Member consists of whitish or light grey, thick-bedded to crudely bedded, quartzose sandstones having thickness of 2-4 m (Figs 2, 3a-d). These rocks are covered by pink to reddish dolomitic marlstones and thin beds of grey or pink intraformational carbonate conglomerates. In section Melyane and two nearby ouctrops (Gaganitsa, Kostentsi), the thickness of the unit reaches up to $15-20 \mathrm{~m}$. In these exposures, the lower part of the Glavatsi Member is represented by the same quartz- 

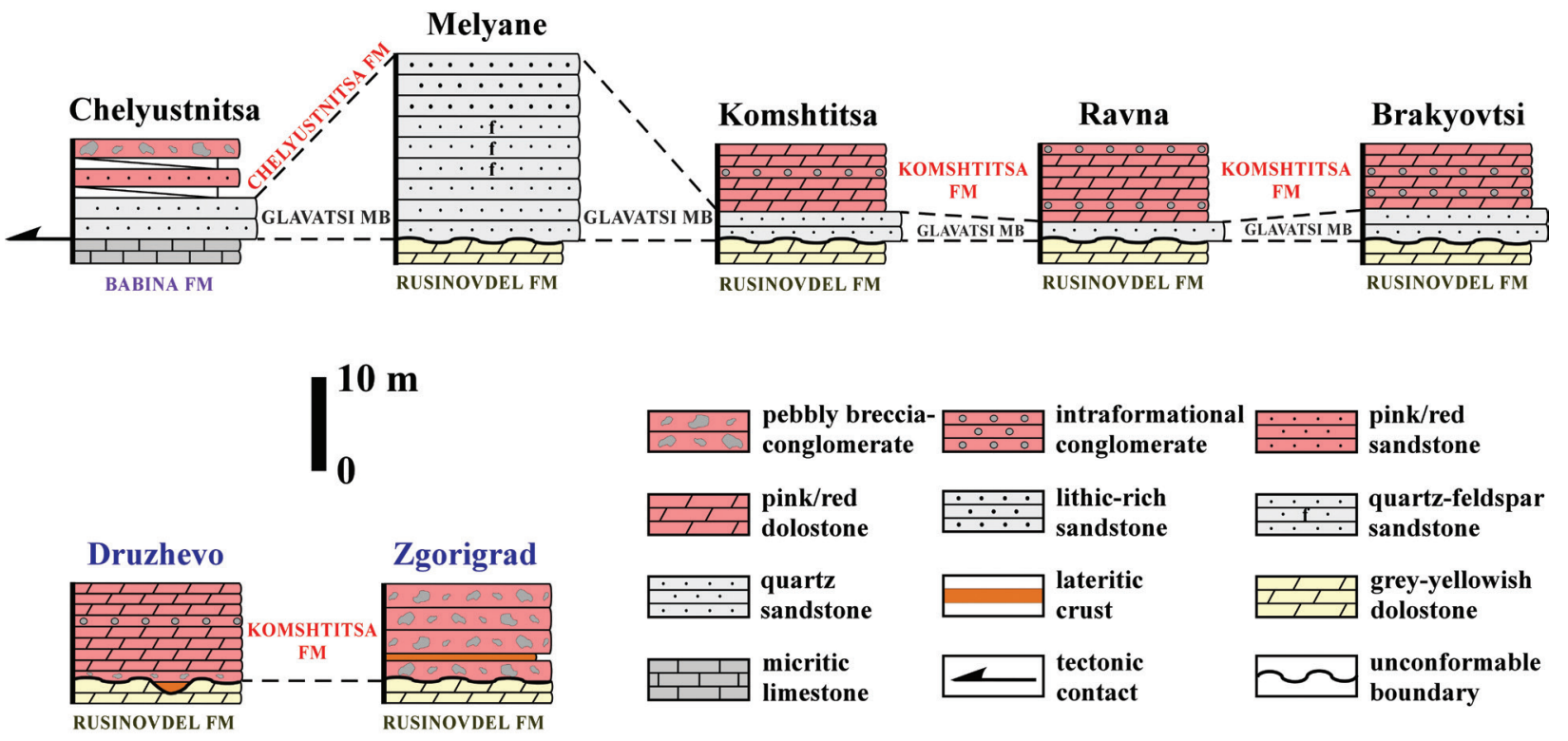

Fig. 2. Stratigraphic-lithologic logs of the lower part of the Moesian Group in the studied sections and outcrops.

rich sandstones (4-5 m), which grade up-section into light grey, quartz-feldspar sandstones (Fig. 3e), and further upwards into grey or rusty-coloured, lithic-rich sandstones and granule-sized brecciaconglomerates with carbonate extraclasts. The quartzose sandstones overlie, with sharp and uneven contact (its amplitude reaches several decimeters - Fig. 3f), peritidal dolostones of the Rusinovdel Formation (i.e., Iskar Carbonate Group). Only in section Chelyustnitsa and the outcrop north of Belimel Village does the Glavatsi Member have tectonic contact, with rocks of the Babina Formation or the Toshkovdol Formation (Angelov et al., 2007, 2008a), although other researchers have recognised rocks of the Cheshmichka Formation (Tronkov, 1973; Zagorchev and Budurov, 2007). The sandstones of the Glavatsi Member have predominantly massive structure, but trough and planar crossbedding are also locally observed (Fig. $3 g, h$ ).

The lowermost part of the Komshtitsa Formation is exposed in two of the investigated outcrops (Zgorigrad, Druzhevo) from the eastern sector of the study area. It is characterised by the presence of brown or brown-reddish ferruginous crusts (Fig. 2). The thin iron-rich layer $(\sim 1 \mathrm{~cm})$ found by the road towards Ledenika Cave is developed in extraformational pebbly carbonate brecciaconglomerates (Fig. 4a). The ferruginous crust near Druzhevo Village has thickness of several centimetres and occurs within intraformational granule-sized carbonate conglomerates. The latter, and other associated deposits, comprise the infill of a palaeodoline (palaeosinkhole), which has maximum depth of about $1 \mathrm{~m}$ on the karstified surface of dolostones of the Rusinovdel Formation (Fig. 4b). A distinctive feature of the iron-rich crusts is that the carbonate extraclasts or intraclasts show conspicuously smaller size, different colours (ochre, yellowish, orange, or brownish) and traces from dissolution and/ or replacement compared to the host psephitic rocks.

\section{Micropetrography}

Under the microscope, the quartzose sandstones of the Glavatsi Member show mineralogically homogeneous texture $(\geq 97 \%)$ composed of very fine to very coarse

Fig. 3. Thick-bedded to crudely bedded sandstones of the Glavatsi Member: $a-c$ ) Quartz arenites in section Chelyustnitsa (a), section Komshtitsa ( $b$ ) (arrow shows hammer for scale), and the outcrop in Krivi Potok locality $(c)$; $d$ ) Quartz arenites (GM) overlying dolostones of the Rusinovdel Formation (RF) in section Brakyovtsi; e) Feldspathic arenites in section Melyane; $f$ ) Unconformable boundary (exposure surface) between dolostones of the Rusinovdel Formation (RF) and quartz arenites of the Glavatsi Member $(\mathrm{GM})$ in section Melyane; $g$ ) Cross-bedded quartz arenites outcropping in the Klokotish plateau; $h$ ) Planar cross-bedding in lithic arenites from section Melyane. 

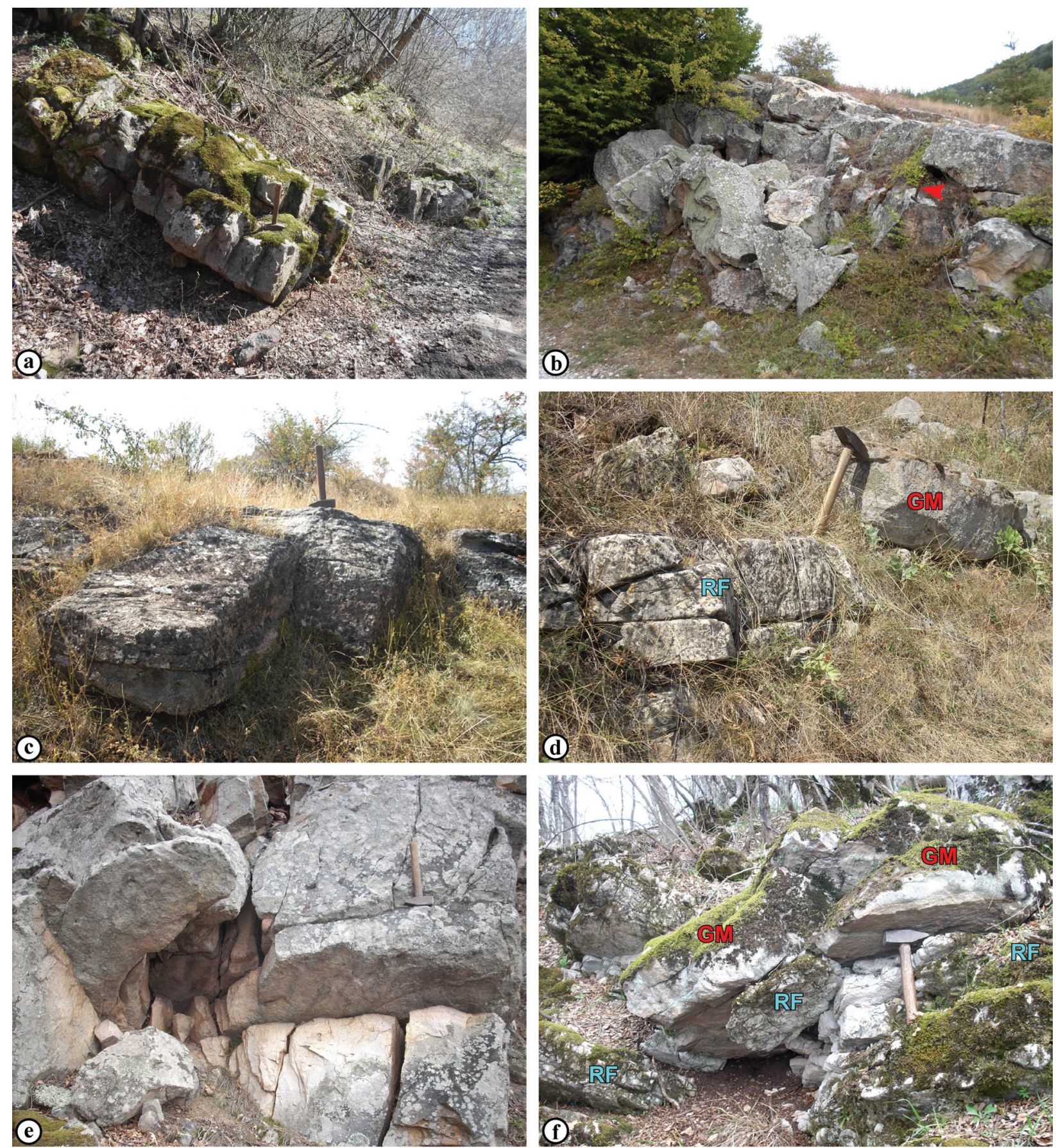

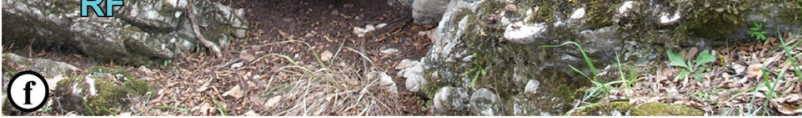
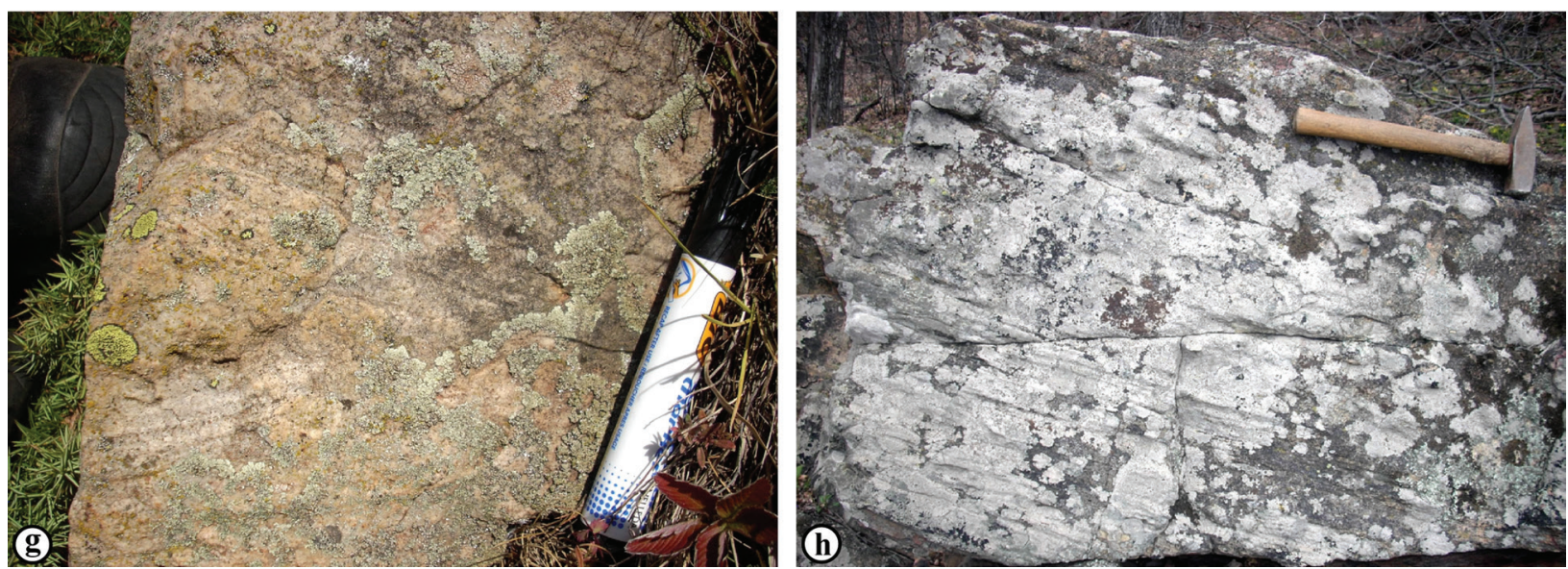

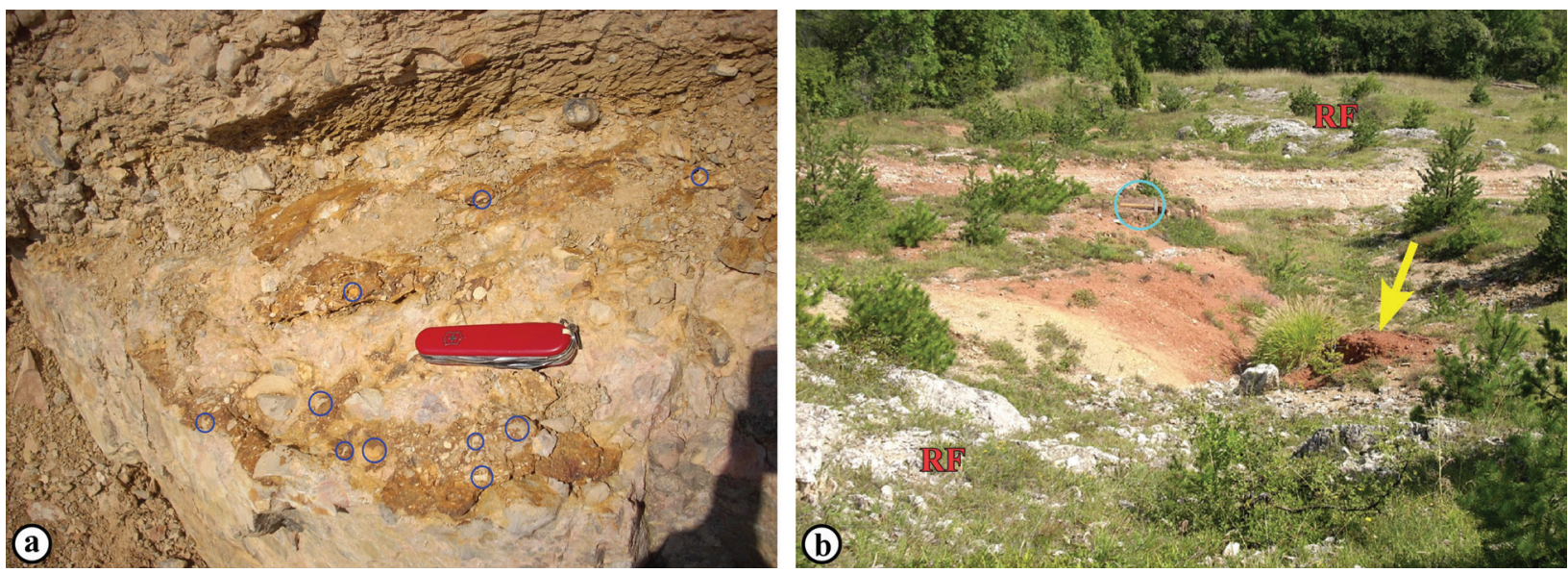

Fig. 4. a) Relicts of thin lateritic crust (brown) developed in pebbly carbonate brecciaconglomerates. Note the smaller size, different colours and traces from dissolution and/or replacement (circles) of carbonate clasts compared to the host rock. Outcrop of the basal part of the Komshtitsa Formation by the road from Zgorigrad Village to Ledenika Cave; $b$ ) Palaeosinkhole in dolostones of the Rusinovdel Formation (RF) infilled with red-coloured continental deposits of the Komshtitsa Formation. Centimetre-thick lateritic crust occurs within intraformational carbonate conglomerates (arrow). Outcrop near Druzhevo Village (circle shows hammer for scale).

(0.063-1.4 mm) quartz grains (Table 1). The latter are poorly sorted in most samples (Fig. $5 a, b$ ), while moderate sorting is rare (Fig. 5c). The detrital grains have variable but, in general, low degree of roundness and sphericity. The grain contacts are mainly tangential and convex-concave, with local occurrences of microstylolites and triple junctions $\left(\sim 120^{\circ}\right)$ also observable
(Fig. $5 d$ ). The quartz is predominantly monocrystalline and non-undulatory to weakly undulatory $\left(<5^{\circ}\right)$, but some grains exhibit undulose extinction $\left(>5^{\circ}\right)$ or distinct zones of extinction with sharp boundaries (i.e., polygonised quartz). Mineral inclusions of tourmaline, rutile, zircon, apatite, and white mica are rarely present, while fluid inclusions are a typical characteristic.

Table 1

Modal composition of framework grains (in \%) in sandstones of the Glavatsi Member. Abbreviations: Qt - total quartz, F - feldspar, Lt - total lithics, Qm-monocrystalline quartz, Qp - polycrystalline quartz, Ls - sedimentary rock fragments including chert, Lp - plutonic lithic fragments.

\begin{tabular}{lccccccc}
\hline Sandstone type*/grains & $\mathrm{Qt}$ & $\mathrm{F}$ & $\mathrm{Lt}$ & $\mathrm{Qm}$ & $\mathrm{Qp}$ & $\mathrm{Ls}$ & $\mathrm{Lp}$ \\
\hline quartz arenite & 99.4 & 0.2 & 0.4 & 91.7 & 7.7 & 0.4 & - \\
quartz arenite & 97.7 & 2.0 & 0.3 & 78.9 & 18.8 & 0.3 & - \\
quartz arenite & 98.5 & 1.4 & 0.1 & 84.0 & 14.5 & 0.1 & - \\
quartz arenite & 97.0 & 2.4 & 0.6 & 92.0 & 5.0 & 0.6 & - \\
quartz arenite & 99.3 & 0.2 & 0.5 & 94.2 & 5.1 & 0.5 & - \\
quartz arenite & 99.7 & 0.1 & 0.2 & 92.9 & 6.8 & 0.2 & - \\
quartz arenite & 99.8 & 0.1 & 0.1 & 90.7 & 9.1 & 0.1 & - \\
quartz arenite & 98.6 & 1.2 & 0.2 & 89.1 & 9.5 & 0.2 & - \\
quartz arenite & 99.8 & 0.1 & 0.1 & 95.1 & 4.7 & 0.1 & - \\
quartz arenite & 99.1 & 0.4 & 0.5 & 92.6 & 6.5 & 0.5 & - \\
subfeldsarenite & 86.2 & 12.7 & 1.1 & 79.6 & 6.6 & - & 1.1 \\
subfeldsarenite & 91.7 & 8.2 & 0.1 & 86.4 & 5.3 & 0.1 & - \\
feldsarenite & 72.7 & 24.0 & 3.3 & 64.0 & 8.7 & 0.1 & 3.2 \\
feldsarenite & 68.7 & 27.8 & 3.5 & 59.5 & 9.2 & - & 3.5 \\
sublitharenite & 77.4 & 2.1 & 20.5 & 61.3 & 16.1 & 20.5 & - \\
sublitharenite & 76.2 & 3.9 & 19.9 & 61.0 & 15.2 & 19.9 & - \\
calclitharenite & 65.3 & 0.8 & 33.9 & 45.8 & 19.5 & 33.9 & - \\
calclitharenite & 71.0 & 1.2 & 27.8 & 52.2 & 18.8 & 27.8 & - \\
\hline
\end{tabular}

* The samples of quartz arenites were collected from all studied sections and outcrops; samples of the other sandstone types originate from the Melyane-Gaganitsa-Kostentsi region. 

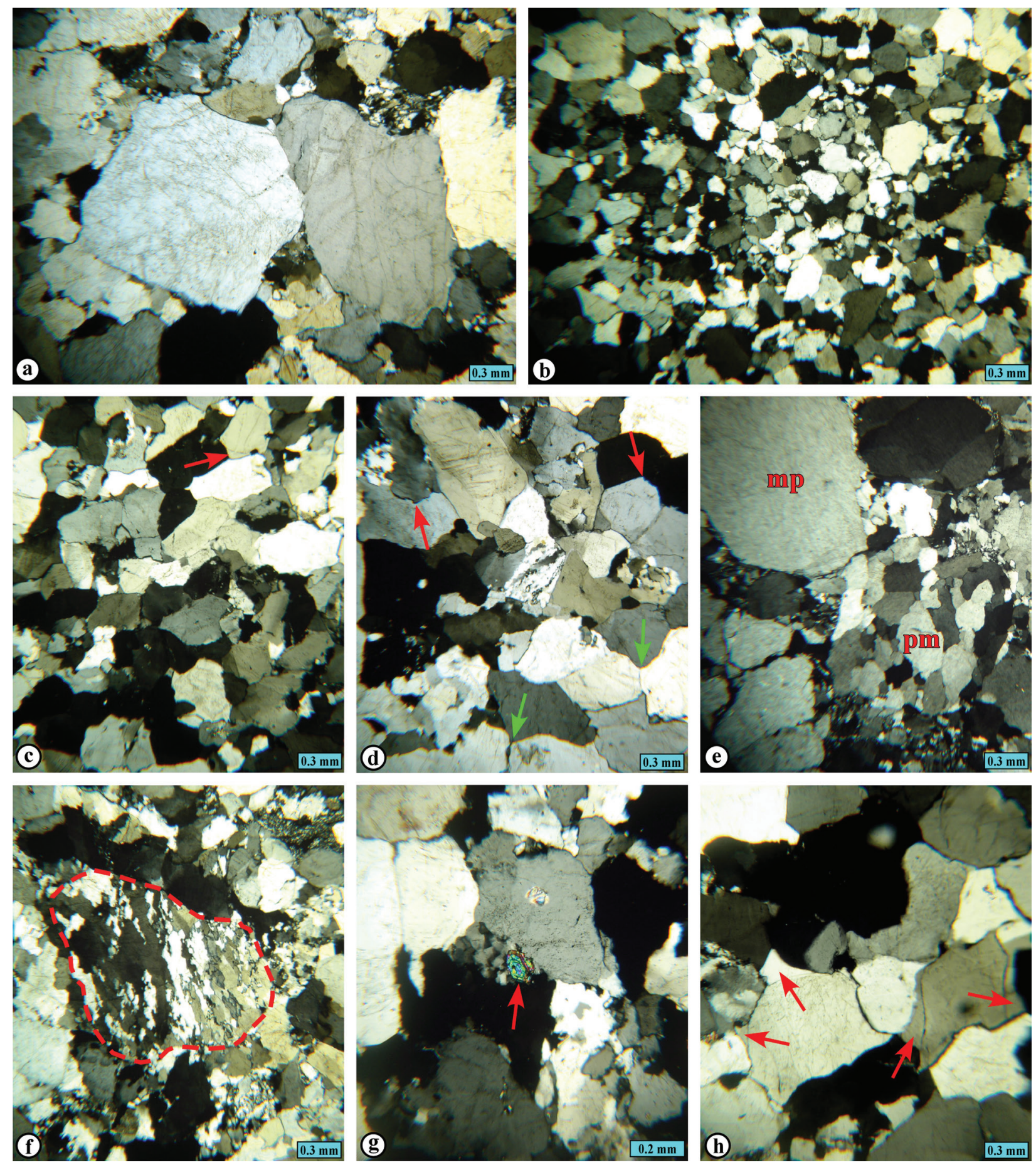

Fig. 5. First-cycle quartz arenites having high mineralogical maturity but low textural maturity: $a$ ) Coarse, non-undulose monocrystalline quartz grains with abundant strings of fluid inclusions; $b$ ) Very fine-grained to medium-grained texture composed of poorly sorted detrital quartz with predominantly low degree of roundness; $c$ ) Moderately sorted sandstone (arrow indicates recycled grain with abraded quartz overgrowth); $d$ ) Strong compaction evidenced by convex-concave grain contacts (red arrows) and triple junctions at $120^{\circ}$ (green arrows); $e$ ) Coarse grains of monocrystalline plutonic quartz with weak undulose extinction (mp) and polycrystalline metamorphic quartz ( $\mathrm{pm}) ; f$ ) Polycrystalline quartz grain (dashed line) composed of numerous elongated crystals with various sizes and crenulated boundaries; $g$ ) Detrital zircon having well-preserved euhedral habit (arrow); $h$ ) Clear quartz cement (arrows) forming syntaxial overgrowths on adjacent monocrystalline grains. All microphotographs are in cross-polarised light. 
Reworked sedimentary quartz is locally distinguished by abraded and rounded quartz overgrowths and/or brownish rims. The subordinate polycrystalline quartz grains have various numbers, shapes, and sizes of the individual crystals, whose boundaries are smooth, crenulated, or sutured (Fig. $5 e, f$ ). Detrital grains of microcrystalline quartz are very scarce $(<1 \%)$ and probably represent chert rock fragments. The amount of variously altered alkali feldspar (mostly perthite) is also insignificant and slightly increases (up to 3\%) in those samples taken from the top part of vertical intervals with quartzose sandstones. The rare heavy minerals are largely dominated by zircon and tourmaline, commonly showing well-preserved euhedral habit (Fig. $5 g$ ). In some thin-sections, small intergranular pores $(\leq 5 \%$ of the rock volume) are filled with clear quartz cement, which may form syntaxial overgrowths on one of the adjacent monocrystalline grains (Fig. 5h), including reworked sedimentary quartz with abraded overgrowths. The sandstones are characterised by high compositional but low textural maturity and are classified as quartz arenites in the QFR ternary diagram (Fig. 6).

The quartz-feldspar sandstones are dominated by detrital quartz (65-90\%), and feldspar grains are present in variable amounts (10-30\%). Granitoid rock fragments appear in some thin-sections $(<5 \%)$, while chert lithics are quite scarce $(\leq 0.1 \%)$. A general trend up-section is marked by enrichment in detrital feldspar and decreasing amount of quartz. The framework grains are poorly to moderately sorted, showing commonly low to medium degree of roundness and sphericity. The quartz grains exhibit very similar morphological and optical characteristics to the quartz arenites. The fresh or altered feldspars comprise perthite (Fig. 7a), microcline (Fig. 7b), and orthoclase, plus rare albite, oligoclase, and grains with granophyric intergrowths (Fig. 7c). The heavy-mineral grains are represented mainly by zircon, tourmaline, and rutile, but more unstable minerals, such as amphibole, sphene, apatite, and epidote, occur in some thin-sections. The sandstones contain small amounts (up to $5 \%$ ) of quartz or blocky calcite cement. In the ternary classification diagram, the rocks are plotted in the fields of subfeld-

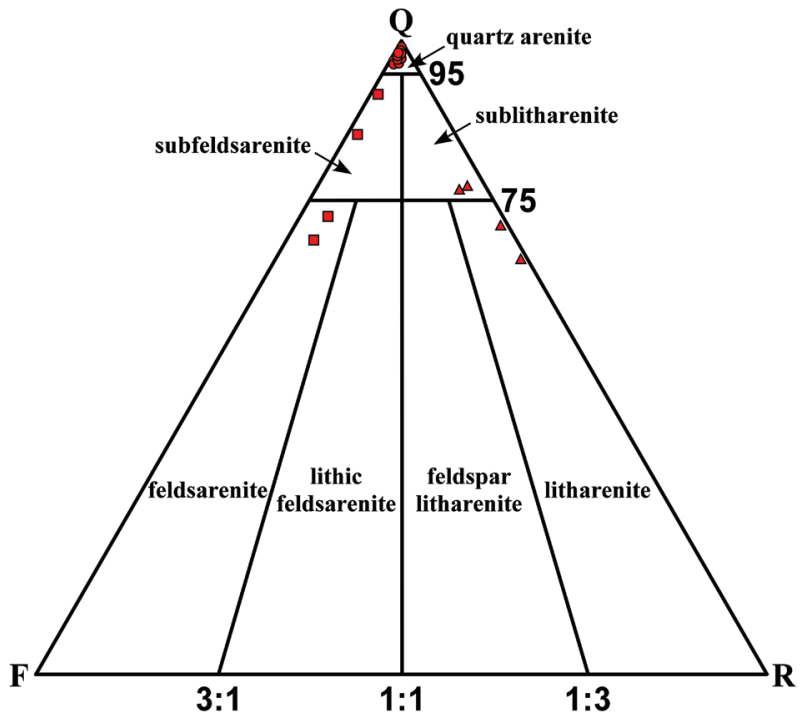

Fig. 6. Classification diagram for detrital framework composition of sandstones (after Folk et al., 1970) with plotted samples from the Glavatsi Member. Note: the same symbols are used in Figs 10-12.

sarenites and feldsarenites. These sandstones have slightly higher textural maturity but lower mineralogical maturity compared to the quartz arenites.

The lithic-rich sandstones of the Glavatsi Member consist of dominant quartz (65-75\%), subordinate carbonate lithics (20-35\%), and scarce feldspar grains $(<5 \%)$. Upwards in the section, the amount of carbonate lithics increases at the expense of detrital quartz. Monocrystalline quartz prevails over polycrystalline grains (Fig. $7 d$ ), but the ratio between both types is significantly lower $(3.2 \pm 0.8)$ relative to the quartz

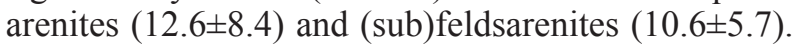
Moreover, a higher amount of elongated monocrystalline grains with undulose extinction is observed (Fig. $7 e, f$ ). In some samples, the quartz grains are characterised by solution pits and/or embayments (Fig. $7 g$ ). The carbonate extraclasts originate from

Fig. 7. Feldspathic arenites $(a-c)$ and lithic arenites $(d-g)$ from section Melyane: $a)$ Moderately sorted subfeldsarenite with feldspar grains dominated by perthite (arrows); $b$ ) Poorly sorted subfeldsarenite with detrital microcline grains (red arrows) and minor amount of calcite cement (green arrows); c) Feldsarenite containing granitoid rock fragment (dashed line) and detrital grain with granophyric intergrowths (arrow); $d-f$ ) Poorly sorted calclitharenites containing angular detrital quartz and variously rounded limestone extraclasts (dashed lines). Arrows indicate polycrystalline quartz (with more than three individual crystals) and monocrystalline grains with elongated shape suggesting increased contribution from a metamorphic source; $g$ ) Sublitharenite consisting of detrital quartz, carbonate lithics and blocky calcite cement (cc). Most quartz grains are characterised by solution pits and/or embayments (arrows) implying intensive chemical weathering in the source area. All microphotographs are in cross-polarised light. 
limestones of the Iskar Carbonate Group including lime mudstones and bioclastic, peloidal or oolitic wackestones, and packstones. The sand-sized detrital grains are poorly to moderately sorted, having generally low degree of roundness, although the carbonate lithics may also be well rounded. Other textural constituents comprise white mica, altered biotite, heavymineral grains (zircon, rutile, tourmaline, amphibole, sphene, apatite, epidote, chlorite, opaques), and vari- ous amounts (10-20\%) of blocky calcite cement. The sandstones are classified as sedimentary litharenites (calclitharenites) and sublitharenites. Their compositional maturity is distinctly lower, and their textural maturity is slightly higher compared to the other sandstone types.

In thin-sections, the ferruginous crusts display a simple mineralogical composition including abundant iron oxyhydroxides, randomly dispersed detrital
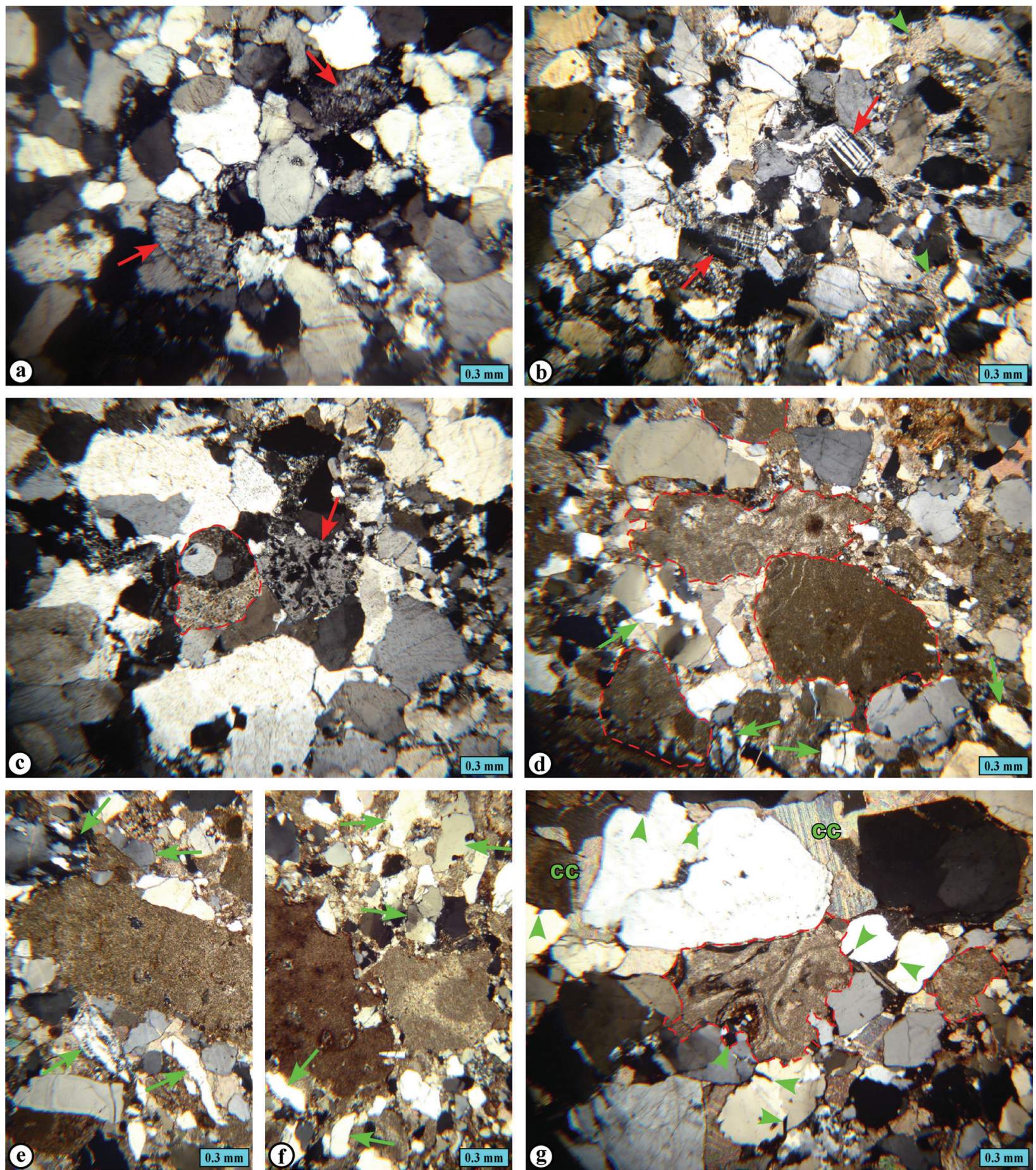
quartz grains (Fig. 8), and some strongly altered carbonate lithics or intraclasts. The former occur as redbrownish cryptocrystalline groundmass or vaguely outlined aggregates having oval, subspherical, or irregular shape (i.e., forming small nodules). The poorly sorted silt- to fine sand-sized quartz grains are entirely monocrystalline and non-undulatory. Their degree of roundness is difficult to estimate because of the significant corrosion (i.e., embayments and solution pits) along their periphery. Goethite was determined by X-ray diffractometry as the main mineral forming

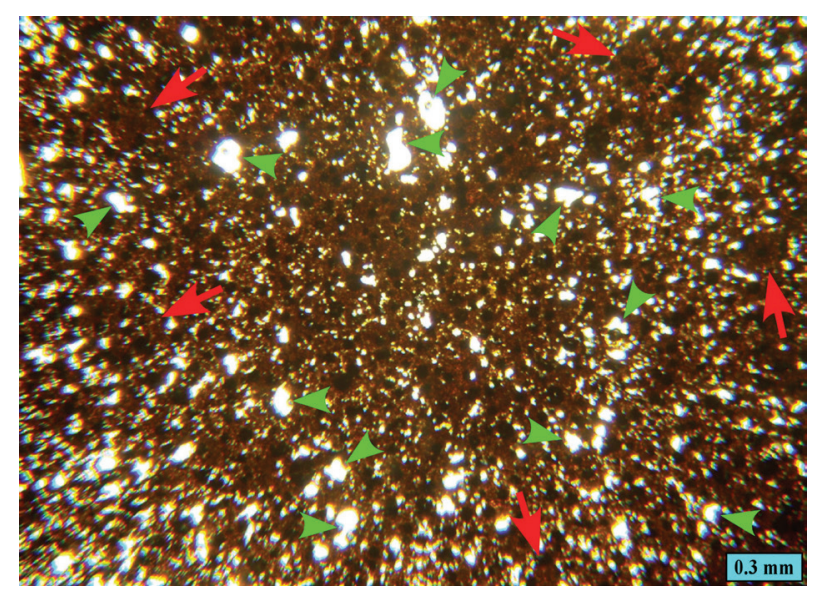

Fig. 8. Laterite crust consisting of red-brown matrix with predominant goethite (based on XRD data) and randomly dispersed detrital quartz grains. The latter display traces from significant corrosion, i.e., embayments and solution pits, along their periphery (green arrows). Small ferruginous nodules are delineated in some sectors of the matrix (red arrows). Microphotograph is in plane-polarised light. the matrix, and other identified phases include quartz, gibbsite, halloysite, and kaolinite (Fig. 9). The broad term "ironstone" can be used to describe the ferruginous crusts, thus avoiding any genetic connotation (see Tanner and Khalifa, 2010; Afify et al., 2015).

\section{MAJOR-ELEMENT CHEMISTRY OF THE SANDSTONES}

The major element concentrations of the sandstones are presented in Table 2. Analytical data show close values of the major oxides for the quartz arenites $(n=6)$. These rocks are very rich in $\mathrm{SiO}_{2}(95.73 \pm 1.17 \%)$, with the main source of silica being detrital quartz, plus quartz cement and chert fragments where available. Among the other major oxides, the highest content is shown by $\mathrm{Al}_{2} \mathrm{O}_{3}(1.15 \pm 0.31 \%)$, and the rest oxides are characterised by very low values $(<1 \%)$ with narrow ranges. In comparison, the samples from subfeldsarenites and feldsarenites $(\mathrm{n}=2)$ are depleted in $\mathrm{SiO}_{2}$ (90.11-92.53\%) but enriched in $\mathrm{Al}_{2} \mathrm{O}_{3}(2.80-3.92 \%)$, $\mathrm{Fe}_{2} \mathrm{O}_{3}(0.38-0.55 \%), \mathrm{Na}_{2} \mathrm{O}(0.17-0.31 \%)$, and $\mathrm{K}_{2} \mathrm{O}$ (1.32-3.08\%). These differences are related mainly to the presence of detrital feldspar and plutonic lithic fragments, as the $\mathrm{K}_{2} \mathrm{O} / \mathrm{Na}_{2} \mathrm{O}$ ratio is constantly larger than unity, thus reflecting the predominance of K-feldspar over plagioclase. The sublitharenite and calclitharenite samples $(n=2)$ have lowest values for $\mathrm{SiO}_{2}(80.15-83.63 \%)$ and highest values for $\mathrm{Fe}_{2} \mathrm{O}_{3}(0.87-0.93 \%), \mathrm{MgO}(0.75-0.80 \%), \mathrm{CaO}$ (6.77$9.88 \%)$, and $\mathrm{Na}_{2} \mathrm{O}(0.47-0.55 \%)$, while the contents of $\mathrm{Al}_{2} \mathrm{O}_{3}(2.10-2.87 \%)$ and $\mathrm{K}_{2} \mathrm{O}(1.65-2.11 \%)$ are similar to the feldspathic sandstones. The notably high values of $\mathrm{CaO}$ are due to the presence of carbonate rock fragments and cement. The plotted chemical compositions in the classification diagrams of Pettijohn et al. (1972)

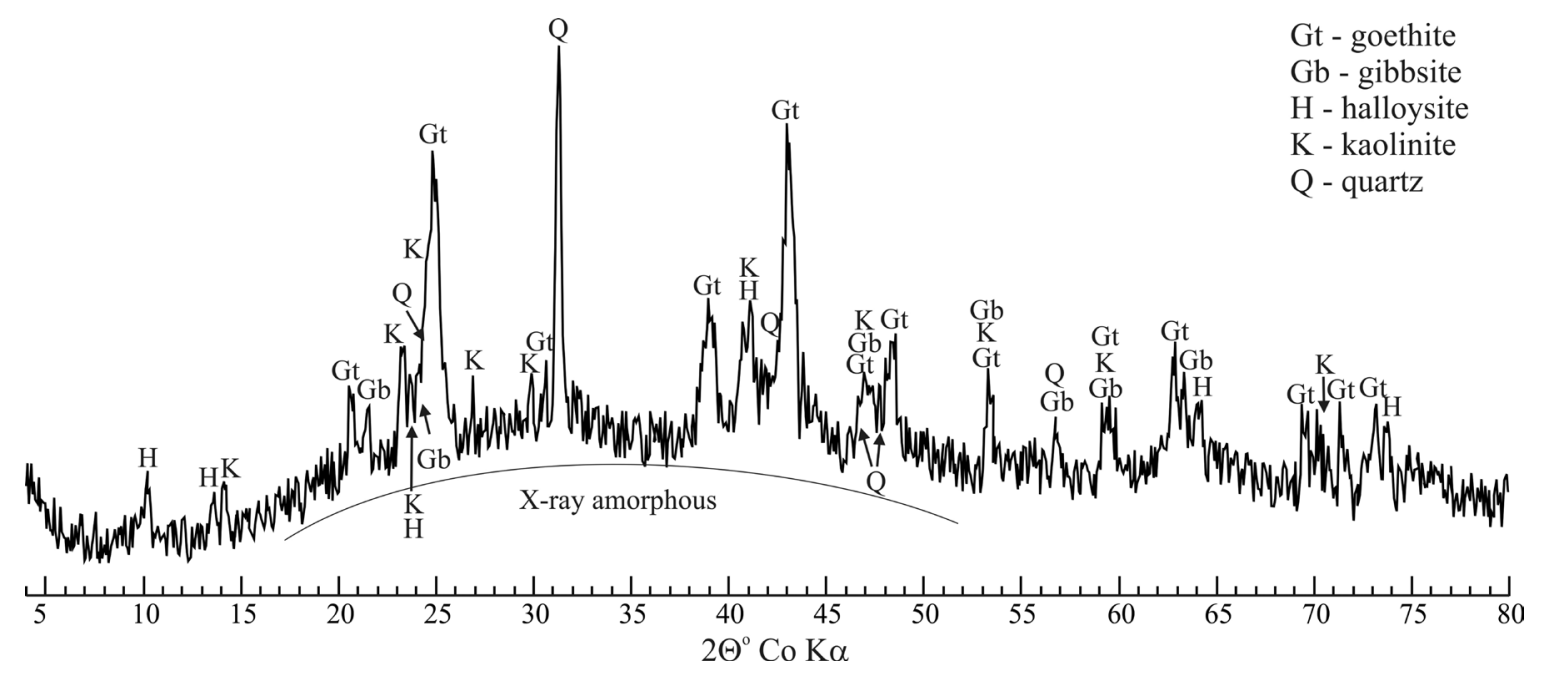

Fig. 9. X-ray diffractogram of the matrix of a lateritic crust. The sample was taken from the basal part of the Komshtitsa Formation in the outcrop near Zgorigrad Village by the road towards Ledenika Cave. 
Table 2

Major oxides (weight \%) in sandstones of the Glavatsi Member.

\begin{tabular}{lrrrrrrrrrr}
\hline Sample* & $1-\mathrm{Ch}$ & $1-\mathrm{Mn}$ & $2-\mathrm{Mn}$ & $3-\mathrm{Mn}$ & $4-\mathrm{Mn}$ & $1-\mathrm{Ks}$ & $1-\mathrm{Km}$ & $1-\mathrm{Kp}$ & $1-\mathrm{Br}$ & $1-\mathrm{Rv}$ \\
\hline $\mathrm{SiO}_{2}$ & 94.56 & 95.58 & 92.53 & 80.15 & 83.63 & 90.11 & 95.81 & 96.69 & 95.21 & 96.51 \\
$\mathrm{TiO}_{2}$ & 0.09 & 0.07 & 0.04 & 0.06 & 0.05 & 0.06 & 0.10 & - & 0.08 & - \\
$\mathrm{Al}_{2} \mathrm{O}_{3}$ & 1.08 & 1.36 & 2.80 & 2.10 & 2.87 & 3.92 & 1.15 & 0.89 & 1.46 & 0.97 \\
$\mathrm{Fe}_{2} \mathrm{O}_{3}$ & 0.13 & 0.09 & 0.55 & 0.93 & 0.87 & 0.38 & 0.14 & 0.27 & 0.22 & 0.15 \\
$\mathrm{MnO}$ & 0.01 & - & 0.01 & 0.02 & 0.02 & 0.01 & 0.01 & - & 0.01 & 0.01 \\
$\mathrm{MgO}$ & 0.49 & 0.70 & 0.30 & 0.75 & 0.80 & 0.51 & 0.47 & 0.53 & 0.58 & 0.46 \\
$\mathrm{CaO}$ & 0.99 & 0.38 & 0.40 & 9.88 & 6.77 & 0.48 & 0.47 & 0.30 & 0.37 & 0.42 \\
$\mathrm{Na}$ & 0.02 & 0.01 & 0.31 & 0.47 & 0.55 & 0.17 & 0.01 & 0.01 & 0.02 & 0.01 \\
$\mathrm{~K}_{2} \mathrm{O}$ & 0.07 & 0.09 & 1.32 & 1.65 & 2.11 & 3.08 & 0.08 & 0.09 & 0.13 & 0.08 \\
$\mathrm{P}_{2} \mathrm{O}_{5}$ & 0.01 & - & - & 0.01 & 0.01 & - & 0.01 & - & - & - \\
$\mathrm{H}_{2} \mathrm{O}-$ & 0.40 & 0.23 & 0.39 & 0.26 & 0.24 & 0.38 & 0.30 & 0.30 & 0.42 & 0.30 \\
L.O.I. & 1.71 & 1.65 & 1.26 & 3.40 & 2.20 & 1.33 & 1.19 & 1.09 & 1.08 & 1.27 \\
Total & 99.56 & 100.16 & 99.91 & 99.68 & 100.12 & 100.43 & 99.74 & 100.17 & 99.58 & 100.18 \\
\hline
\end{tabular}

* Samples originate from the following sections and outcrops: 1-Ch - Chelyustnitsa; 1-Mn, 2-Mn, 3-Mn, 4-Mn - Melyane; 1-Ks Kostentsi; 1-Km - Komshtitsa; 1-Kp - Krivi potok; 1-Br - Brakyovtsi; 1-Rv - Ravna.

and Herron (1988) correlate well with the micropetrographic data, especially for the quartz arenites (Fig. 10a,b), and thus help to illustrate differences in the mineralogical maturity based on the $\mathrm{SiO}_{2} / \mathrm{Al}_{2} \mathrm{O}_{3}$ ratio. The relatively poor distinction between the feldspathic and lithic sandstones in both diagrams is due to: a) low contents of $\mathrm{Fe}_{2} \mathrm{O}_{3}, \mathrm{Na}_{2} \mathrm{O}$, and $\mathrm{K}_{2} \mathrm{O}$; b) close values of $\mathrm{SiO}_{2}$; c) presence of limestone rock fragments and calcite cement in the lithic arenites; and d) some limitations of the parameters $\mathrm{Na}_{2} \mathrm{O} / \mathrm{K}_{2} \mathrm{O}$ and $\mathrm{Fe}_{2} \mathrm{O}_{3} / \mathrm{K}_{2} \mathrm{O}$ used in the two classifications, respectively (see comments by Lindsey, 1999).

\section{INTERPRETATION OF THE RESULTS AND DISCUSSION}

\section{Depositional environment}

The regional unconformable boundary between the marine deposits of the Iskar Carbonate Group and the continental strata of the Moesian Group represents a discontinuity surface (sensu Clari et al., 1995), i.e., recording a break in sedimentation (Chatalov, 2016). This abrupt lithological contact is further interpreted as an exposure surface with distinct dissolution features reflecting formation of minor epikarst morphology on the carbonate substrate. Therefore, the initial deposition of quartz-rich sands occurred after some period of subaerial exposure, non-deposition, and karstification (Chatalov, 2016). The sandstones of the Glavatsi Member can be defined as continental deposits on the basis of their limited lateral occurrence, variable thickness, presence of palaeokarst features in the underlying marine rocks, and upwards transition into other continental deposits. The lack of diagnostic features for tidal, shoreface, or shallow marine sedimentation, such as wave ripples, heterolithic bedding, reactivation surfaces, hummocky cross-stratification, or high textural maturity (e.g., Chakraborty and Sensarma, 2008; Went, 2013), as well as marine body and trace fossils, likewise supports a continental origin of the sandstones. Moreover, the locally observed trough cross-bedding, along with the absence of textural evidence for aeolian reworking, i.e., well-sorted and well-rounded quartz grains (Dott, 2003; Garzanti, 2017), suggests alluvial depositional environment (see also Mader and Chatalov, 1992). The psephitic rocks with abundant carbonate clasts that host the thin ironstone crusts show characteristics of fluvial deposits (Chatalov and Stefanov, unpublished results). The extraformational brecciaconglomerates are interpreted as depositional products of alluvial fans that were transported by stream flows and/or debris flows (i.e., Blair and McPherson, 1994). In turn, the intraformational conglomerates represent fills of ephemeral channels and/or sheetflood deposits formed on an alluvial plain, thus corresponding to Type 1 of reworked calcretes sensu Gómez-Gras and Alonso-Zarza (2003).

\section{Sedimentological indicators for tropical humid palaeoclimate}

Quartz arenites are widespread in Proterozoic and some Phanerozoic (mostly Lower Palaeozoic) strata but are relatively scarce today (Pettijohn et al., 1972; Chandler, 1988; Dott, 2003; Young, 2013). These sandstones are believed to be mainly multicyclic in origin (Suttner et al., 1981) and may also form as a result of postdepositional alteration producing so called "diagenetic quartz arenites" (e.g., McBride, 1987; Khalifa, 2017). A third mechanism postulates 

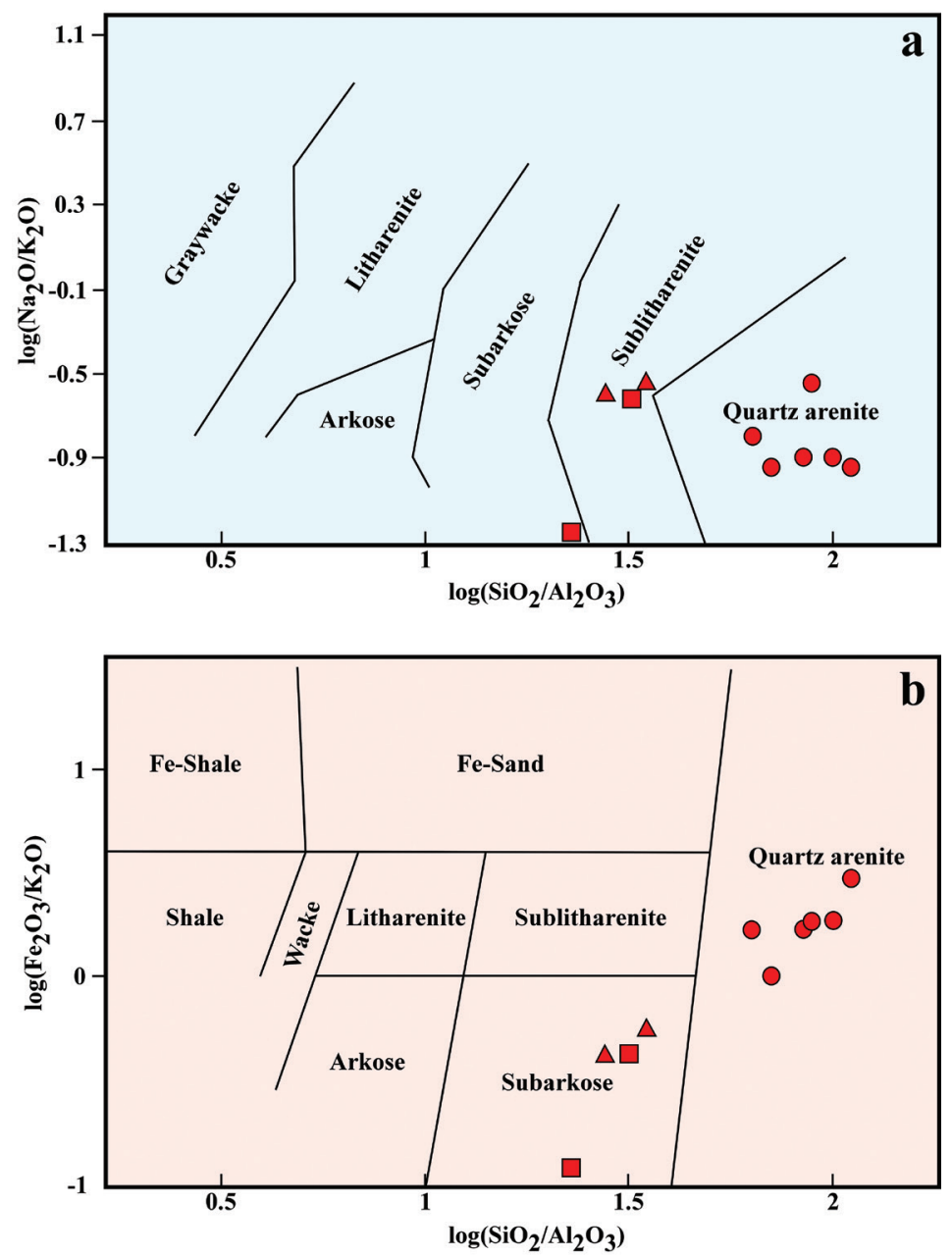

Fig. 10. Classification diagrams based on chemical composition of sandstones with plotted analytical data for samples from the Glavatsi Member: $a$ ) After Pettijohn et al. (1972); b) After Herron (1988).

that some siliciclastic sediments and rocks, strongly enriched in detrital quartz, record extreme conditions of formation, i.e., a unique combination of tropical climate, low relief, and slow sedimentation rate (Suttner et al., 1981). Such compositionally mature sands that are products of intensive chemical weathering in warm to hot humid climate may originate from a variety of source rocks (Garzanti, 2017). While granitoids seem to be the optimal source (Chandler, 1988; Young, 2013), volcanic provenance (Smyth et al., 2008) and mixed sources of detrital quartz, including recycled sedimentary rocks (Bernet et al., 2007; Biernacka, 2012), have also been recognised. Several examples of first-cycle quartz arenites are known from modern tropical environments (Franzinelli and Potter, 1983; Johnsson et al., 1988; Van de Kamp, 2010; Garzanti et al. 2013; Schneider et al., 2016) and Precambrian or Phanerozoic deposits (Suttner and Dutta, 1986; Akhtar and Ahmad, 1991; Dott, 2003; Avigad et al. 2005; Roy and Roser, 2013; Nowrouzi et al., 2014; Spencer et al., 2016).
Diagenetic alteration can be ruled out as a major formative mechanism for the continental quartz arenites of the Glavatsi Member because of a lack of evidence for large-scale dissolution or replacement of other detrital components (i.e., feldspar and/or lithics), for example, oversized pores, abundant carbonate or silica cement, severely etched framework grains, and replacements by clay or carbonate minerals. Considering the other two hypotheses, some micropetrographic characteristics of the sandstones imply that they are not virtually recycled deposits, but rather represent first-cycle quartz arenites. These depositional features include high compositional maturity, low textural maturity, presence of unabraded zircon and tourmaline grains, almost complete absence of lithic fragments, no inverse relationship between feldspar content and grain size, and lack of maturation upwards in the section (see Dott, 2003; van Hattum et al., 2006). Therefore, tropical humid climate must have been a prime control on the sandstone formation, although relief, tectonic regime, source area, and transport were also 
important factors. This general conclusion is corroborated by using the discriminant diagrams for modal framework and chemical compositions of first-cycle sediments from Suttner and Dutta (1986) and Weltje (1994). The quartz arenites are plotted in the fields in- dicating pronounced humidity in conditions of tropical climate and low relief (Fig. $11 a-c$ ). In the same diagrams, the plotted compositions of samples from the feldspathic and lithic arenites outline a clear temporal trend of reduced humidity with less-intensive weather-
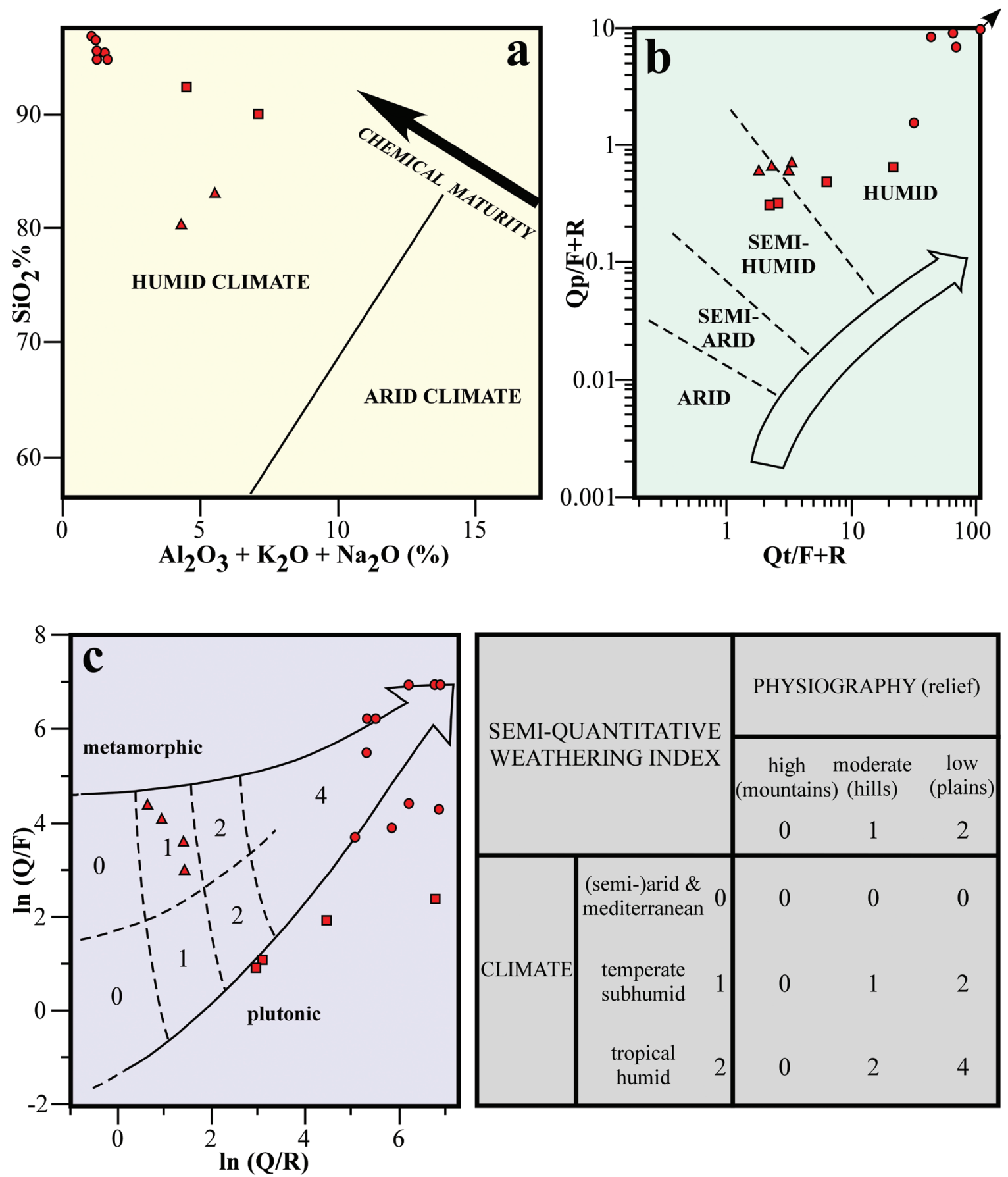

Fig. 11. Discrimination diagrams for chemical and modal framework compositions of first-cycle sediments with plotted samples from the Glavatsi Member: $a$ ) Chemical maturity of sandstones as a function of climate (after Suttner and Dutta, 1986); b) Bivariant $\log / \log$ plot of the $\mathrm{Qp} /(\mathrm{F}+\mathrm{R})$ ratio against the $\mathrm{Qt} /(\mathrm{F}+\mathrm{R})$ ratio related to climate conditions of sandstone deposition (after Suttner and Dutta, 1986). Arrow at the upper right corner indicates six samples from quartz arenites plotted out of the diagram field; $c$ ) General trend showing relation of sandstone composition to parentage and weathering conditions (left) (after Weltje, 1994); calculation of the semi-quantitative weathering index (right). See text for explanation. 
ing, and probably a change from low to moderate relief. These results are consistent with the micropetrographic data, which point to up-section decreasing mineralogical maturity and only slightly increasing textural maturity of the deposited sand-sized material. The irreversible trend is further illustrated by the appearance of unstable clastic grains, i.e., abundant carbonate lithics and diverse heavy minerals. However, the local occurrence of detrital quartz with embayments and solution pits in the calcite-cemented lithic arenites still reflects the influence of intensive chemical weathering in the source area (see Suttner and Dutta, 1986; Garzanti et al., 2013; Spencer et al., 2016; Garzanti, 2017). It should be noted that the scarcity of such corrosion features in the quartz arenites and feldspathic arenites may be due to the strong mechanical compaction and pressure solution (with local precipitation of quartz cement) that mask the effects of earlier dissolution on the detrital grains.

The provenance of the first-cycle quartz-rich sandstones was closely related to the sediment source area, i.e., lithology of the parent rocks. Some characteristics of the framework grains in the quartz arenites and (sub)feldsarenites are indicative of plutonic felsic rocks as a main source of siliciclastic material, for example, the predominance of monocrystalline quartz showing low angle of undulosity and abundant fluid inclusions (Basu et al., 1975; Bernet and Basset, 2005; Smyth et al., 2008). The polycrystalline grains composed of 2-3 non-undulose, commonly subequant crystals with straight to slightly curved intercrystal boundaries were probably also derived from granitoid rocks. The presence of greater amounts of K-feldspar (mostly perthite) than plagioclase, detrital grains with granophyric texture, and plutonic lithics in the feldspathic arenites further supports a plutonic igneous source. Micropetrographic evidence for subordinate contribution from low-grade to high-grade metamorphic rocks includes: monocrystalline undulose quartz commonly having elongated grain shape; polygonised quartz grains; polycrystalline quartz with more than three crystal units, elongated crystal shapes, and sutured or crenulated intercrystal boundaries; polycrystalline quartz with more than three non-undulose large crystals having polyhedral outlines, smooth intercrystal boundaries, and interfacial angles of $120^{\circ}$ at triple junctions (Basu et al., 1975; Young, 1976; Bernet and Basset, 2005; Smyth et al., 2008). It is noteworthy that the larger amount of such metamorphic quartz is a distinct feature of the sublitharenites and calclitharenites. An additional source for all sandstone types was related to erosion, reworking, and redeposition of material derived from siliciclastic and/or carbonate sedimentary rocks. Thus, extraclasts originating from Triassic limestones represent a major textural component of the lithic arenites, while minor amounts of chert fragments and reworked quartz grains with overgrowths are recognised in the quartz arenites and feldspathic arenites. In addition, the moderate sorting of predomi- nantly subangular to subrounded grains in several samples from the latter two sandstone types implies that some detrital quartz and feldspar were derived from immature siliciclastic rocks. Several potential sources of non-carbonate detrital material for the sandstones of the Glavatsi Member can be inferred, taking into account the present-day exposures of diverse rock complexes across the study area and in adjacent regions. These include Lower Palaeozoic low-grade and highgrade metamorphic rocks, Carboniferous granitoids, Upper Palaeozoic and Lower Triassic siliciclastic deposits. The relationship between provenance, climate, and sandstone framework composition is demonstrated in the discrimination diagrams proposed by Suttner et al. (1981) and Weltje (1994). In the first diagram, the climate conditions are fairly consistent with the above interpretations, but the provenance is shifted toward a metamorphic source (Fig. 12a). In the second diagram, there is a good correspondence between the temporal climate change and source rock interpretations based on micropetrography, although the plots of the lithic arenites indicate a metamorphic source (Fig. 11c). Another QFR diagram from Suttner and Dutta (1986) shows the relationships between climate, tectonic setting (field boundaries after Dickinson et $a l ., 1983$ ), and the sandstone composition (Fig. 12b). Most samples from the Glavatsi Member are plotted in the cratonic interior and transitional continental fields of the continental block setting, which reflects quartzose and arkosic sandstones derived from granitoid and/or gneissic sources of stable craton interiors with low relief. In turn, the lithic arenites are plotted in the field indicating recycled orogenic source, which is due to the large presence of rock fragments from sedimentary strata exposed to erosion. In the same diagram, all plotted samples clearly indicate weathering in humid to subhumid climate conditions. Some discrepancies in the three diagrams can be explained by the fact that, with increased weathering, sands from continental terrains converge toward a supermature quartz arenite end-member, and hence the imprint left by source rock composition and tectonic setting becomes obscured (Johnsson, 1990; van Hattum et al., 2006; Smyth et al., 2008; Garzanti, 2017).

The formation of ferruginous (ironstone) crusts in sediments may result from: a) surface or near-surface processes related to pedogenesis and/or weathering; b) non-pedogenic cementation of previous deposits, mostly related to groundwater fluctuation; c) diagenetic alteration driven by the interaction of reducing subsurface fluids and oxidised meteoric waters; and d) combination of several mechanisms encompassing hydrogenetic, diagenetic, and hydrothermal processes (see Afify et al., 2015, and references therein). The third and fourth hypotheses can be ruled out for the studied ironstones by a lack of petrographic evidence for their diagenetic or hydrothermal origin, e.g., iron oxyhydroxide concretions, pipes, impregnations, banding, or other structures cutting across the pri- 

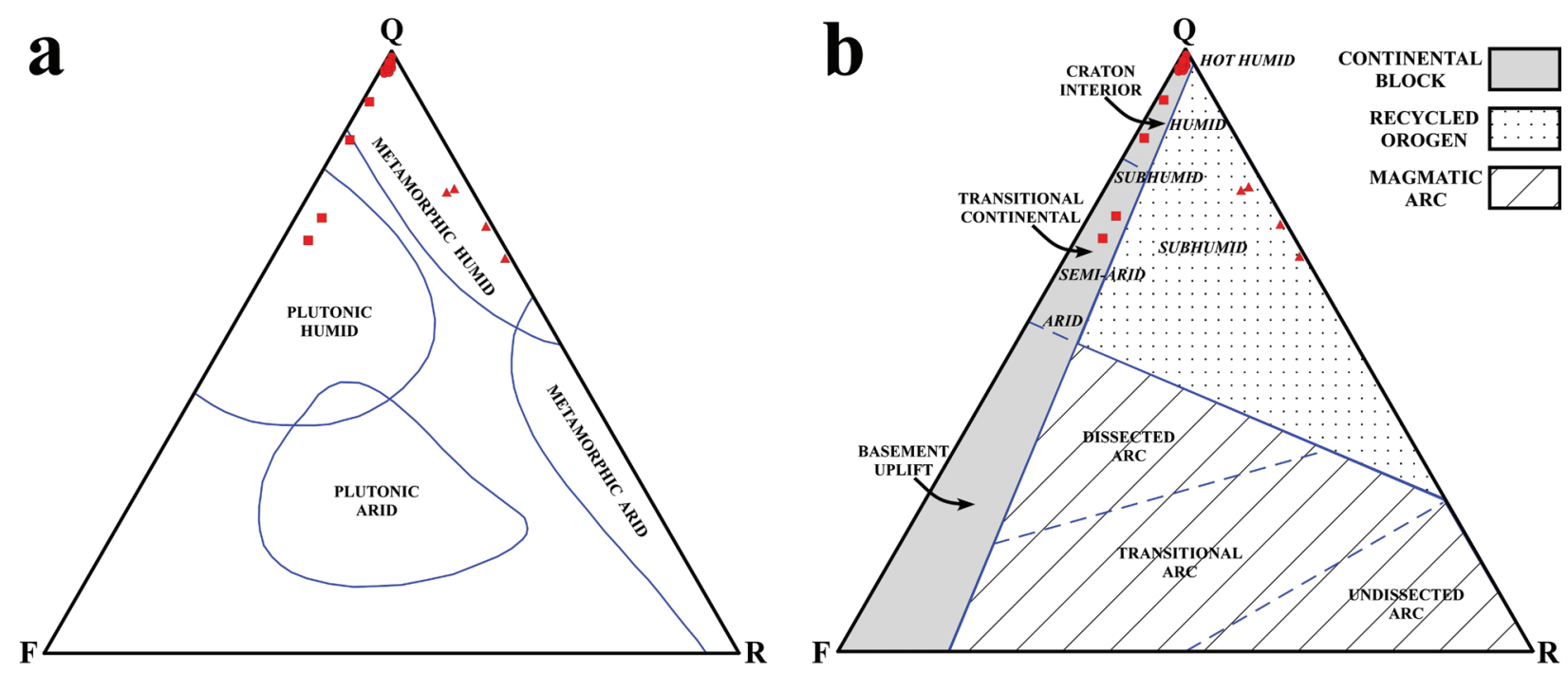

Fig. 12. QFR ternary diagrams for modal framework composition of sandstones with plotted samples from the Glavatsi Member: a) Diagram showing the effect of source rock and climate on sandstone composition (after Suttner et al., 1981); b) Diagram showing relations between climate, tectonic setting and sandstone composition (after Suttner and Dutta, 1986). Provenance field boundaries after Dickinson et al. (1983). See text for explanation.

mary bedding (e.g., Chan et al., 2000; Balsamo et al., 2013; Afify et al., 2015). Therefore, the ferruginous crusts represent either laterites, i.e., residual materials formed by in situ rock breakdown, which attain elevated iron contents through autochthonous enrichment within the weathering profile, or ferricretes, i.e., host sediments with allochthonous enrichment of iron, for example, by groundwaters or aeolian dust (sensu Aleva, 1994; Widdowson, 2007). Distinction in practice between these two genetic types is difficult, because diagnostic features are commonly absent, and also because many lateritic profiles are subsequently modified by introduction of allochthonous iron-rich materials, or conversely, ferricretes can be subjected to weathering processes in situ and thus evolve toward more lateritic-type profiles (Widdowson, 2007). In the present case, distinguishing between laterite and ferricrete is hindered by the lack of well-developed weathering profile (i.e., laterite) or alteration profile (i.e., ferricrete), as well as some textural characteristics of the ferruginous crusts that are common to both products, for example, dissolution of the detrital quartz forming embayments (see Borger and Widdowson, 2001; Spencer et al., 2016), and preserved but strongly altered components of the parent rock, i.e., carbonate lithoclasts. Nevertheless, the absence of basement rocks as a possible source of iron and multiple or stacked ferricrete zones indicative of groundwater table changing with time (cf. Tanner and Khalifa, 2010) suggests a lateritic origin of the ironstone crusts. Also, ferricretes develop preferentially as footslope accumulations or within topographic de- pressions, such as former lakes, swamps, valley floors, peritidal zones, or estuaries, because their formation is dependent upon the accumulation of iron-rich debris or solutes transported from higher landscape positions (Widdowson, 2007, and references therein). In contrast, laterite formation is favoured in geomorphological environments characterised by near-horizontal surfaces and such a gentle palaeotopography across the study area was inherited in the early Carnian from subaerially exposed carbonate strata after the demise of a homoclinal ramp system (Chatalov, 2016). Further implications stem from the lack of petrographic evidence for ferruginous cementation, distribution of ferruginous material controlled primarily by sediment permeability, or mechanically derived and transported iron-rich components in the host rocks (e.g., clasts from earlier ferruginized rocks). Conversely, the studied ironstone crusts developed in matrix-rich psephitic deposits, and immature sediments readily lend themselves to lateritisation (Widdowson, 2007). Lastly, the presence of first-cycle quartz arenites elsewhere in the basal part of the Upper Triassic continental succession is consistent with tropical humid climate favouring the coeval formation of laterites.

The mineral assemblage in the matrix of the ferruginous crusts, i.e., including goethite, gibbsite, halloysite and kaolinite, is typical for laterites (Widdowson, 2007; Velde and Meunier, 2008). During lateritisation, dissolution of silicate minerals was a dominant process resulting in the depletion of mobile (alkali and alkaline earth) elements, loss of $\mathrm{Si}$, and increase of $\mathrm{Fe}$ and $\mathrm{Al}$ content in the weathered residue. The identified 
minerals may have formed either directly from the alteration of primary minerals in the immature psephitic deposits or via a series of pathways involving the formation of intermediary sheet silicates and clays, which were then themselves broken down, stripped of their mobile elements and silica, and eventually converted to aluminium and iron oxyhydroxides. The lateritic crusts formed primarily under three conditions, which promoted intense chemical weathering and mineral alteration: a) a favourable climate, typified by seasonal, high annual precipitation and high mean annual temperature; b) a favourable geomorphological environment, characterised by limited runoff and lack of aggressive erosion; and c) a relative tectonic stability (Widdowson, 2007). In particular, the high amounts of goethite and small amounts of gibbsite indicate extreme weathering conditions, i.e., intense rainfall and high temperatures (Velde and Meunier, 2008), as well as a long weathering time, which must have persisted over at least tens of thousands of years (Aleva 1994). Similarly, the presence of halloysite reflects a continuously humid environment, unlike kaolinite, which is usually formed in soils that experience periods of drying (Churchman et al., 2016).

To sum up, the presence of first-cycle quartz-rich sandstones and thin lateritic crusts in the basal levels of the Moesian Group suggests warm to hot humid palaeoclimate conditions. The upwards transition from quartz arenites, through feldspathic arenites, to lithic arenites in the Glavatsi Member reflects decreasing humidity and reduced weathering rate, and this climate change terminated the development of lateritisation processes. The progressive aridisation is further indicated by sedimentological characteristics of the overlying siliciclastic and carbonate deposits of the Komshtitsa Formation or Chelyustnitsa Formation (formed in fluvial and playa environments), which unambiguously attest to semi-arid climate conditions (Mader and Chatalov, 1992; Chatalov and Stefanov, unpublished results).

In comparison, similar lithological associations of continental quartz arenites and laterites in Palaeoproterozoic successions from Finland (Lahtinen and Nironen, 2010) and the USA (Spencer et al., 2016), and in Cambro-Ordovician strata from North Africa and Southwest Asia (Avigad et al., 2005), were interpreted as unequivocal indicators for warm to hot humid climatic conditions. An inverse temporal change of the climate regime (i.e., from warm semi-arid, through warm humid, to hot humid) during the deposition of first-cycle quartz-rich sediments was demonstrated by Suttner and Dutta (1986) in their study of Permian-Triassic fluvial sandstones from India.

\section{Implications for the effect of the Carnian Humid Episode}

The Early Triassic was a time of extreme hothouse conditions, while mainly greenhouse conditions per- sisted during the Middle and Late Triassic, showing a non-zonal climate pattern controlled by a global monsoon system (Mutti and Weissert, 1995; Preto et al., 2010; Sun et al., 2012; Holz, 2015; Trotter et al., 2015). The predominantly arid to semi-arid climatic regime was interrupted by regionally or locally manifested humid and semi-humid phases, for example, in some Western Tethys areas (Mutti and Weissert, 1995; Berra et al., 2010; Stefani et al., 2010; Haas et al., 2012). The most distinctive climate change during the Triassic occurred in the late early Carnian (Preto et al., 2010) when high temperatures (Hornung et al., 2007a; McKie, 2014; Trotter et al., 2015; Sun et al., 2016), along with increased humidity, favoured intensive weathering and erosion, development of large fluvial systems, and increased siliciclastic input into marine basins (Simms and Ruffell, 1989). The enhanced terrigenous runoff, freshwater influx and increased nutrient supply caused reduced carbonate productivity, reef crisis, and biotic turnover resulting in decline or demise of shallow marine carbonate systems across the Western Tethys (Simms et al., 1995; Hornung and Brandner, 2005; Hornung et al., 2007a; Gattolin et al., 2015). Karstification and lateritic palaeosols developed locally on subaerially exposed Western Tethyan carbonate platforms (Mutti and Weissert, 1995; Breda et al., 2009; Escudero-Mozo et al., 2014). Significant siliciclastic input related to the strong humidity was also recorded in marginal marine, deep marine, and continental environments (Rigo et al., 2007; Jaglarz, 2010; Kozur and Bachmann, 2010; Rostasi et al., 2011; Sýkora et al., 2011; Arche and López-Gómez, 2014; McKie, 2014). The pronounced late Julian to earliest Tuvalian climate perturbation was originally named Carnian Pluvial Episode (Simms and Ruffell, 1989), but later different terms have been used in the literature, e.g., Carnian Pluvial Event (Rigo et al., 2007), Middle Carnian Wet Intermezzo (Kozur and Bachmann, 2010), Carnian Humid Episode (Ruffell et al., 2016), or Carnian Pluvial Phase (Mueller et al., 2016b). Initially considered as a regional phenomenon across the Western Tethys and the Germanic Basin, the effect of the Carnian Humid Episode is now recognised on a global scale, spanning from tropical to high latitudes in the northern and southern hemispheres (Prochnow et al., 2006; Hornung et al., 2007b; Andrews et al., 2014; Arche and López-Gómez, 2014; Nakada et al., 2014; Dal Corso et al., 2015; Holz, 2015; Mueller et al., 2016a; Ruffell et al., 2016; Sun et al., 2016, Mader et al., 2017). Different hypotheses have been proposed to explain its causes. One of the main theories postulates that rising $\mathrm{CO}_{2}$ levels from the eruption of the Wrangellia large igneous province in Panthalassa triggered a global warming and associated increased rainfall (Furin et al., 2006; Dal Corso et al., 2012, 2015; Xu et al., 2014; Ruffell et al., 2016). The precise onset, duration, continuity, and intensity of the Carnian Humid Episode are still under intense debate (Hornung et al., 2007a; Rigo et al., 
2007; Kozur and Bachmann, 2010; Roghi et al., 2010; Lukeneder et al., 2012; Bialik et al., 2013; Dal Corso et al., 2015; Mueller et al., 2016b; Sun et al., 2016).

During the Triassic, Bulgaria was located in the subtropical belt $\left(20-30^{\circ} \mathrm{N}\right)$ of the NW Tethys (Marcoux et al., 1993; Muttoni et al., 2000), where semi-arid to arid climatic conditions prevailed (Preto et al., 2010). Sedimentological analysis of the upper Olenekian to lower Carnian marine succession exposed in the western Balkanides indicates warm and dry climate during the development of a carbonate ramp (Chatalov, 2013, 2016). Demise of the ramp system occurred as a consequence of relative sea-level fall and subaerial exposure, and the ensuing break in sedimentation was accompanied by formation of minor epikarst morphology on the emerged carbonate substrate. The relatively poor development of dissolution features was due to near-surface karst processes presumably controlled by a short duration of emergence and subhumid climate conditions before the onset of continental sedimentation (Chatalov, 2016). The latter started after some period of non-deposition and karstification, and was largely controlled by further intensification of the humid climate (i.e., pluvialisation), as suggested by the deposition of first-cycle quartz arenites and the formation of lateritic crusts. This pronounced climate change was most likely related to the global Carnian Humid Episode. Although direct age determinations for the Moesian Group are lacking, its variegated deposits have been defined as Carnian-Norian on the basis of their stratigraphic position (Tronkov, 1969). The main evidence comes from immediately underlying strata of the Iskar Carbonate Group, which are biostratigraphically dated as early Carnian; biostratigraphically significant bivalve and brachiopod taxa have been found in peritidal dolostones from the upper part of the Rusinovdel Formation (Tronkov, 1969) and subtidal limestones of the Cheshmichka Formation (Tronkov, 1973).

The quartz arenites and lateritic crusts are difficult to correlate in terms of their time of formation taking into account the great differences in the thicknesses and lithology of the Moesian Group across the study area (see Tronkov, 1960; Goranov, 1961; Tronkov et al., 1965; Mader and Chatalov, 1992; Zagorchev and Budurov, 2007). However, the coeval occurrence of these deposits in the lowermost part of the Upper Triassic continental succession implies their contemporaneous, climate-controlled formation during a distinctive time interval, i.e., the Carnian Humid Episode. It is noteworthy that some researchers have unambiguously proved the occurrence of several humid pulses (i.e., alternating with drier phases) in the Western Tethys realm and the Germanic Basin during the late Julian and earliest Tuvalian (Kolar-Jurkovsek and Jurkovsek, 2010; Kozur and Bachmann, 2010; Roghi et al., 2010; Stefani et al., 2010; Haas et al., 2012; Bialik et al., 2013; Mueller et al., 2016b). Accordingly, it is possible that the formation of quartzose sandstones and lateritic crusts was related to different humid pulses within the same episode. Such an assumption is supported, in particular, by the alternation of ironstone crusts with siliciclastic deposits unaffected by laterisation (see Fig. 4a).

Other important evidence for the possible effect of the Carnian Humid Episode includes the decreasing compositional maturity of the quartz-rich sandstones upwards in the Glavatsi Member and the disappearance of lateritic crusts above the basal part of the Komshtitsa Formation. These irreversible changes reflect a gradual transition from humid through subhumid climatic conditions, and finally, to stable semiarid climate, which is also indicated by the overlying thick fluvial and playa deposits of the Komshtitsa Formation or Chelyustnitsa Formation (see Mader and Chatalov, 1992; Chatalov and Stefanov, unpublished results). The regional character and long duration of the subsequent semi-arid to arid climate regime is further supported by stratigraphic and sedimentological data on the Moesian Group from other areas of the country, for example, in the Moesian Platform (Vaptsarova and Chemberski, 1984) and the Central Balkanides (Mader and Chatalov, 1992), as well as stratigraphic correlations with the Romanian part of the Moesian Platform (Paraschiv, 1982) and the East Serbian part of the Carpatho-Balkanides (Kovács et al., 2011). In the same context, several studies have demonstrated that the Carnian Humid Episode was followed by progressive aridisation and climate stability during the late Carnian and Norian in the Western Tethys realm and adjacent coastal, fluvial, and playa settings (Jaglarz, 2010; Kozur and Bachmann, 2010; Preto et al., 2010; Stefani et al., 2010; Bialik et al., 2013; Holz, 2015; Ortí et al., 2017). Therefore, the available data from the western Balkanides are consistent with the regional palaeoclimate interpretations, emphasizing a temporal relationship between the Carnian Humid Episode and the lithological climate indicators recognised in the basal part of the Moesian Group.

Another Late Triassic humid phase commenced during the latest Norian and largely influenced the sedimentation pattern in some Western Tethys regions and nearby continental areas (e.g., Ciarapica, 2007; Berra et al., 2010; Haas et al., 2012; McKie, 2014; Fijałkowska-Mader, 2015). Accordingly, this significant climate change can be a possible explanation for the formation of first-cycle quartz arenites and lateritic crusts in the studied Upper Triassic sections from NW Bulgaria. However, such an assumption in the present case is unrealistic, considering the long time interval ( $20 \mathrm{Ma}$ ) between the termination of marine carbonate sedimentation in the early Carnian and the onset of continental sedimentation in the latest Norian. Furthermore, there is unequivocal evidence for persistent humid and cooler climate conditions during the subsequent Rhaetian and across the Triassic/Jurassic boundary both in the Western Tethys realm and adja- 


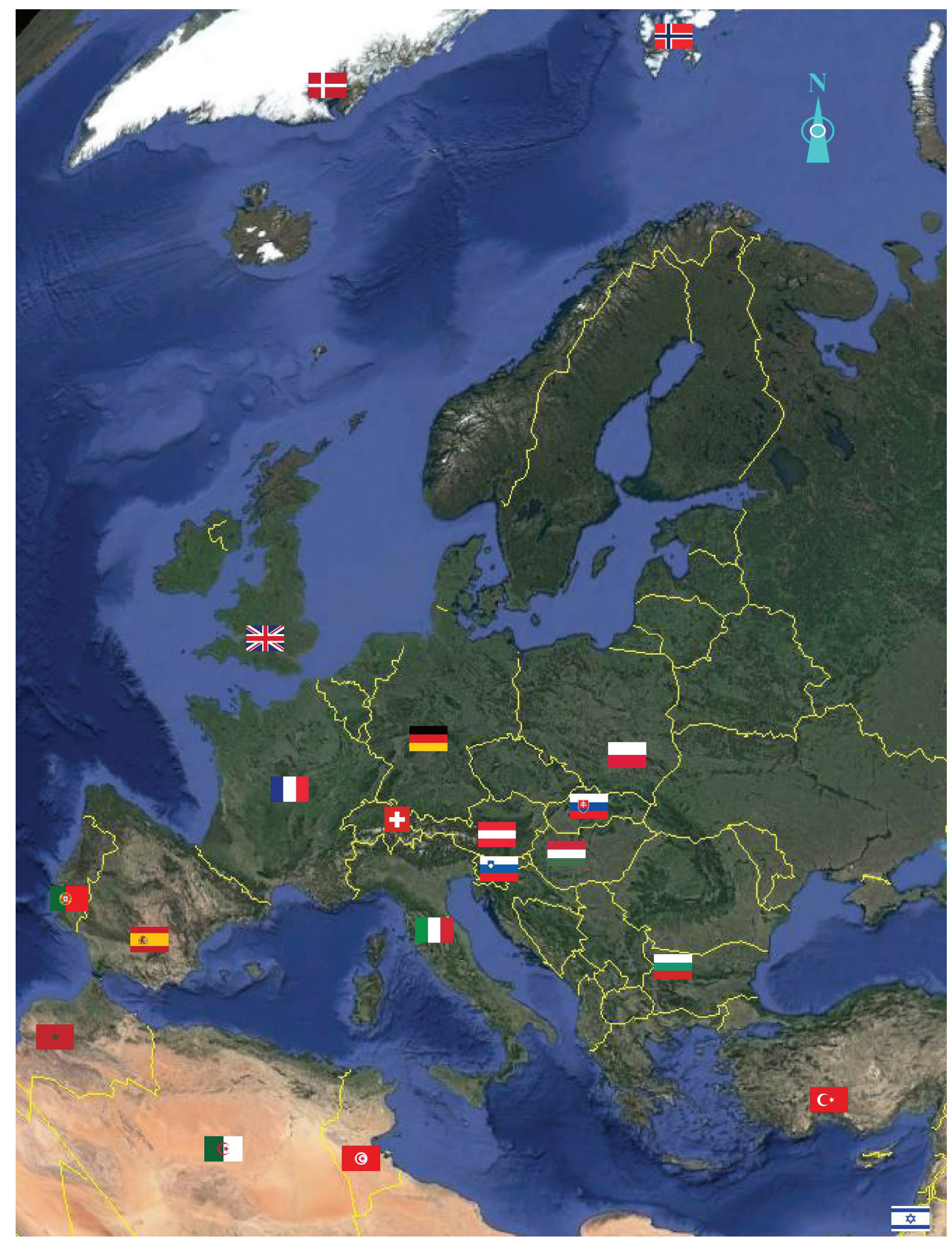

Fig. 13. Geographic distribution of localities with documented lithological and biological proxies for the Carnian Humid Episode in Europe and adjacent countries in Africa and Asia (compiled from Preto et al., 2010; Roghi et al., 2010; Arche and López-Gómez, 2014; Dal Corso et al., 2015; Ruffell et al., 2016, and references therein). Additonal data are used for Slovakia (Sýkora et al., 2011), Greenland (Andrews et al., 2014), Poland (Fijałkowska-Mader, 2015), Svalbard (Mueller et al., 2016a), and Morocco (Mader et al., 2017). The present study reports the first possible evidence for the effect of the Carnian Humid Episode from Eastern Europe. Map is based on a Google Earth image. 
cent areas (e.g., Urošević and Radulović, 1990; Berra et al., 2010; Preto et al., 2010; Götz et al., 2011; Haas et al., 2012; Lintnerová et al., 2013; Brański, 2014, and references therein), which contradicts with the long-lasting aridisation after the Carnian Humid Episode.

\section{CONCLUSIONS}

Lithological indicators for tropical humid palaeoclimate conditions have been identified in the lowermost part of the Upper Triassic continental succession (Moesian Group) exposed in NW Bulgaria. The presence of first-cycle quartz arenites and lateritic crusts suggests that sedimentation and weathering were largely controlled by warm to hot humid climate, while relief, tectonic regime, source area, transport of siliciclastics, sedimentation rate, and time were also important additional factors. Sedimentological characteristics of the quartz-rich sandstones and laterites, stratigraphic and facies relationships with the underlying marine strata and overlying continental deposits, and correlations with Upper Triassic strata from other regions imply the effect of the most distinctive climate change during the Triassic, i.e., the global Carnian Humid Episode. In this context, the present study reports the first geological evidence for a pronounced mid-Carnian climate pluvialisation from Eastern Europe (Fig. 13). It also documents one of the rare occurrences of firstcycle quartz arenites from the stratigraphic record. The new results and interpretations present indirect sedimentological evidence for the stratigraphical range of the Moesian Group in the western Balkanides.

\section{Acknowledgements}

The author is grateful to Y. Stefanov (Sofia University "St Kliment Ohridski") for his cooperation during the fieldwork and important discussions on the topic. T. Stanimirova (Sofia University "St Kliment Ohridski") is thanked for helpfully assisting in the interpretation of the X-ray diffractograms. The analytical work of P. Boteva, V. Georgieva and V. Nakova (Sofia University "St Kliment Ohridski") is also greatly acknowledged.

\section{REFERENCES}

Afify, A.M., Sanz-Montero, M.E., Calvo, J.P., Wanas, H.A. 2015. Diagenetic origin of ironstone crusts in the Lower Cenomanian Bahariya Formation, Bahariya Depression, Western Desert, Egypt. Journal of African Earth Sciences $101,333-349$.

Ajdanlijsky, G. 2008a. Triassic. In: Angelov, V., Hrischev, H. (Eds), Explanatory note to Geological map of the Republic of Bulgaria. Scale 1:50 000. Lakatnik map sheet. Uniscorp, Sofia, 38-52.

Ajdanlijsky, G. 2008b. Triassic. In: Angelov, V., Hrischev, H. (Eds), Explanatory note to Geological map of the Republic of Bulgaria. Scale 1:50 000. Montana map sheet. Uniscorp, Sofia, 15-25.

Akhtar, K., Ahmad, A.H.M. 1991. Single-cycle cratonic quartz arenites produced by tropical weathering: the Nimar sandstone (Lower Cretaceous), Narmada basin, India. Sedimentary Geology 71, 23-32.

Aleva, G.J.J. 1994. Laterites: concepts, geology, morphology and chemistry. International soil reference and information center (ISRIC), Wageningen, $169 \mathrm{pp}$.

Andrews, S.D., Kelly, S.R., Braham, W., Kaye, M. 2014. Climatic and eustatic controls on the development of a Late Triassic source rock in the Jameson Land Basin, East Greenland. Journal of the Geological Society 171, 609-619.

Angelov, V., Antonov, M., Gerdzhikov, S., Petrov, P., Kiselinov, H., Aydanliyski, G. 2007. Geological map of the Republic of Bulgaria. Scale 1:50 000. Montana map sheet. Ministry of Environment and Water and Bulgarian National Geological Survey, Sofia.

Angelov, V., Antonov, M., Gerdzhikov, S., Aydanliyski, G., Petrov, P., Kiselinov, H. 2008a. Geological map of the Republic of Bulgaria. Scale 1:50 000. Chiprovtsi map sheet.
Ministry of Environment and Water and Bulgarian National Geological Survey, Sofia.

Angelov, V., Antonov, M., Gerdzhikov, S., Petrov, P., Kiselinov, H., Aydanliyski, G. 2008b. Geological map of the Republic of Bulgaria. Scale 1:50 000. Berkovitsa map sheet. Ministry of Environment and Water and Bulgarian National Geological Survey, Sofia.

Angelov, V., Antonov, M., Gerdzhikov, S., Petrov, P., Kiselinov, H., Aydanliyski, G., Valev, V. 2009a. Geological map of the Republic of Bulgaria. Scale 1:50 000. Godech map sheet. Ministry of Environment and Water and Bulgarian National Geological Survey, Sofia.

Angelov, V., Antonov, M., Gerdzhikov, S., Petrov, P., Kiselinov, H., Aydanliyski, G., Valev, V. 2009b. Geological map of the Republic of Bulgaria. Scale 1:50 000. Lakatnik map sheet. Ministry of Environment and Water and Bulgarian National Geological Survey, Sofia.

Arche, A., López-Gómez, J. 2014. The Carnian Pluvial Event in Western Europe: new data from Iberia and correlation with the Western Neotethys and Eastern North AmericaNW Africa regions. Earth-Science Reviews 128, 196-231.

Avigad, D., Sandler, A., Kolodner, K., Stern, R.J., McWilliams, M., Miller, N., Beyth, M. 2005. Mass production of Cambro-Ordovician quartz-rich sandstone as a consequence of chemical weathering of Pan-African terranes: environmental implications. Earth and Planetary Science Letters 240, 818-826.

Balsamo, F., Bezerra, F., Vieira, M., Shorti, F. 2013. Structural control on the formation of iron-oxide concretions and Liesegang bands in faulted, poorly lithified Cenozoic sandstones of the Paraiba Basin, Brazil. Geological Society of America Bulletin 125, 913-931. 
Basu, A.S., Young, W., Suttner, L.J., James, W.C., Mack, G.H. 1975. Re-evaluation of the use of undulatory extinction and polycrystallinity in detrital quartz for provenance interpretation. Journal of Sedimentary Petrology 45, 873-883.

Bernet, M., Basset, K. 2005. Provenance analysis by singlequartz-grain SEM-CL/optical microscopy. Journal of Sedimentary Research 75, 492-500.

Bernet, M., Kapoutsos, D., Basset, K. 2007. Diagenesis and provenance of Silurian quartz arenites in south-eastern New York State. Sedimentary Geology 201, 43-55.

Berra, F., Jadoul, F., Anelli, A. 2010. Environmental control on the end of the Dolomia Principale/Hauptdolomit depositional system in the central Alps: coupling sea-level and climate changes. Palaeogeography, Palaeoclimatology, Palaeoecology 290, 138-150.

Bialik, O.M., Korngreen, D., Benjamini, C. 2013. Carnian (Triassic) aridization on the Levant margin: evidence from the M1 member, Mohilla Formation, Makhtesh Ramon, south Israel. Facies 59, 559-581.

Biernacka, J. 2012. Provenance of Upper Cretaceous quartzrich sandstones from the North Sudetic Synclinorium, SW Poland: constraints from detrital tourmaline. Geological Quarterly 56, 315-332.

Blair, T.C., McPherson, J.G. 1994. Alluvial fans and their natural distinction from rivers based on morphology, hydraulic processes, sedimentary processes, and facies assemblages. Journal of Sedimentary Research A64, 450-489.

Borger, H., Widdowson, M. 2001. Indian laterites, and lateritious residues of southern Germany: a petrographic, mineralogical, and geochemical comparison. Zeitschrift für Geomorphologie 45, 177-200.

Boucot, A.J., Chen, X., Scotese, C.R. 2013. Phanerozoic paleoclimate: an atlas of lithologic indicators of climate. SEPM (Society for Sedimentary Geology), Concepts in sedimentology and paleontology 11, 478 pp.

Brański, P. 2014. Climatic disaster at the Triassic-Jurassic boundary - a clay minerals and major elements record from the Polish Basin. Geological Quarterly 58, 291-310.

Breda, A., Preto, N., Roghi, G., Furin, S., Meneguolo, R., Ragazzi, E., Fedele, P., Gianolla, P. 2009. The Carnian Pluvial Event in the Tofane area (Cortina d'Ampezzo, Dolomites, Italy). Geo.Alp 6, 80-115.

Chakraborty, T., Sensarma, S. 2008. Shallow marine and coastal eolian quartz arenites in the Neoarchean-Palaeoproterozoic Karutola Formation, Dongargarh Volcano-sedimentary succession, central India. Precambrian Research 162, 284-301.

Chan, M.A., Parry, W.T., Bowman, J.R. 2000. Diagenetic hematite and manganese oxides and fault-related fluid flow in Jurassic sandstones, southeastern Utah. American Association of Petroleum Geologists Bulletin 84, 1281-1310.

Chandler, F.W. 1988. Quartz arenites: review and interpretation. Sedimentary Geology 58, 105-126.

Chatalov, A. 2013. A Triassic homoclinal ramp from the Western Tethyan realm, Western Balkanides, Bulgaria: integrated insight with special emphasis on the Anisian outer to inner ramp facies transition. Palaeogeography, Palaeoclimatology, Palaeoecology 386, 34-58.

Chatalov, A. 2016. Global, regional and local controls on the development of a Triassic carbonate ramp system, Western Balkanides, Bulgaria. Geological Magazine, doi:10.1017/ S0016756816000923

Chatalov, G. 1980. Two facies types of Triassic in Strandza Mountain, SE Bulgaria. Rivista Italiana di Paleontologia e Stratigrafia 85, 1029-1046.

Chemberski, H., Vaptsarova, A. 1979. The Triassic system in North Bulgaria. I. Stratigraphic principles. Geologica Balcanica 9, 67-108 (in Russian, with English abstract).
Chemberski, H., Vaptsarova, A., Monakhov, I. 1974. Lithostratigraphy of the Triassic variegated terrigenous-carbonate and carbonate sediments studied with deep drilling in Northwestern and Central North Bulgaria. Annual of DSO Geological Exploration 20, 327-341 (in Bulgarian, with English abstract).

Churchman, G.J., Pasbakhsh, P., Lowe, D.J., Theng, B.K.G. 2016. Unique but diverse: some observations on the formation, structure, and morphology of halloysite. Clay Minerals 51, 395-416.

Ciarapica, G. 2007. Regional and global changes around the Triassic-Jurassic boundary reflected in the late NorianHettangian history of the Apennine basins. Palaeogeography, Palaeoclimatology, Palaeoecology 244, 34-51.

Clari, P.A., Della Pierre, F., Martire, L. 1995. Discontinuities in carbonate successions: identification, interpretation and classification of some Italian examples. Sedimentary Geology 100, 97-121.

Dal Corso, J., Gianolla, P., Newton, R.J., Franceschi, M., Roghi, G., Caggiati, M., Raucsik, B., Budai, T., Haas, J., Preto, N. 2015. Carbon isotope records reveal synchronicity between carbon cycle perturbation and the "Carnian Pluvial Event" in the Tethys realm (Late Triassic). Global and Planetary Change 127, 79-90.

Dal Corso, J., Mietto, P., Newton, R.J., Pancost, R.D., Preto, N., Roghi, G., Wignall, P.B. 2012. Discovery of a major negative $\delta^{13} \mathrm{C}$ spike in the Carnian (Late Triassic) linked to the eruption of Wrangellia flood basalts. Geology 40, $79-82$.

Dickinson, W.R., Beard, L.S., Brakenridge, G.R., Erjavec, J.L., Ferguson, R.C., Inman, K.F., Knep, R.A., Lindberg, F.A., Ryberg, P.T. 1983. Provenance of North American Phanerozoic sandstones in relation to tectonic setting. Geological Society of America Bulletin 94, 222-235.

Dott, R.H. 2003. The importance of eolian abrasion in supermature quartz sandstones and the paradox of weathering on vegetation-free landscapes. Journal of Geology 111, 387-405.

Duval, B.C., Cramez, C., Vail, P.R. 1998. Stratigraphic cycles and major marine source rocks. In: de Graciansky, P.-C., Hardenbol, J., Jacquim, T., Vail, P.R. (Eds), Mesozoic and Cenozoic sequence stratigraphy of European basins. SEPM Special Publication 60, 43-52.

Escudero-Mozo, M.J., Martín-Chivelet, J., Goy, A., LópezGómez, J. 2014. Middle-Upper Triassic carbonate platforms in Minorca (Balearic islands): implications for Western Tethys correlations. Sedimentary Geology 310, 41-58.

Fijałkowska-Mader, A. 2015. Record of climatic changes in the Triassic palynological spectra from Poland. Geological Quarterly 59, 615-653.

Flügel, E. 2004. Microfacies of carbonate rocks. Analysis, interpretation, and application. Springer, Berlin-HeidelbergNew York, 976 pp.

Folk, R.L., Andrews, P.B., Lewis, D.W. 1970. Detrital sedimentary rock classification and nomenclature for use in New Zealand. New Zealand Journal of Geology and Geophysics 13, 937-968.

Franzinelli, E., Potter, P.E. 1983. Petrology, chemistry, and texture of modern river sands, Amazon River system. Journal of Geology 91, 23-39.

Furin, S., Preto, N., Rigo, M., Gianolla, P., Crowley, J.L., Bowring, S.A. 2006. High-precision U-Pb zircon age from the Triassic of Italy: implications for the Triassic time scale and the Carnian origin of calcareous nannoplankton and dinosaurs. Geology 34 (12), 1009-1012.

Ganev, M. 1974. Stand der Kenntnisse über die Stratigraphie der Trias Bulgariens. In: Zapfe, H. (Ed.), Die Stratigraphie der alpin-mediterranean Trias: simposium. Schriftenreihe 
der Erdwissenschaftlichen Kommission, Österreichische Akademie des Wissenschaften 2, 93-96.

Garzanti, E. 2017. The maturity myth in sedimentology and provenance analysis. Journal of Sedimentary Research 87, 353-365.

Garzanti, E., Padoan, M., Andò, S., Resentini, A., Vezzoli, G., Lustrino, M. 2013. Weathering and relative durability of detrital minerals in equatorial climate: sand petrology and geochemistry in the East African rift. Journal of Geology $121,547-580$.

Gattolin, G., Preto, N., Breda, A., Franceschi, M., Isotton, M., Gianolla, P. 2015. Sequence stratigraphy after the demise of a high-relief carbonate platform (Carnian of the dolomites): sea-level and climate disentangled. Palaeogeography, Palaeoclimatology, Palaeoecology 423, 1-17.

Gianolla, P., Ragazzi, E., Roghi, G. 1998. Upper Triassic amber from the dolomites (northern Italy). A paleoclimatic indicator?. Rivista Italiana di Paleontologia e Stratigrafia 104, 381-389.

Gnoevaya, N. 1965. Mineralogical-petrographical characteristics of the Triassic in Northwestern Bulgaria. Bulletin of the "Strašimir Dimitrov" Institute of Geology 14, 293-323 (in Bulgarian, with Russian and German abstracts).

Gómez-Gras, D., Alonso-Zarza, A.M. 2003. Reworked calcretes: their significance in the reconstruction of alluvial sequences (Permian and Triassic, Minorca, Balearic Islands, Spain). Sedimentary Geology 158, 299-319.

Goranov, A. 1961. Lithology of the Rhaetian in part of the Western Balkan range. Travaux sur la Géologie de Bulgarie, Série Stratigraphie et Tectonique 3, 75-92 (in Bulgarian, with Russian and English abstracts).

Gornitz, V. 2009. Paleoclimate proxies: an introduction. In: Gornitz, V. (Ed.), Encyclopedia of paleoclimatology and ancient environments. Springer, Dordrecht, 716-720.

Götz, A.E., Ruckwied, K., Barbacka, M. 2011. Palaeoenvironment of the Late Triassic (Rhaetian) and Early Jurassic (Hettangian) Mecsek Coal Formation (south Hungary): implication from macro- and microfloral assemblages. Palaeobiology and Palaeoenvironments 91, 75-88.

Haas, J., Budai, T., Raucsik, B. 2012. Climatic controls on sedimentary environments in the Triassic of the Transdanubian Range (Western Hungary). Palaeogeography, Palaeoclimatology, Palaeoecology 353-355, 31-44.

Herron, M.M. 1988. Geochemical classification of terrigenous sands and shales from core or log data. Journal of Sedimentary Petrology 58, 820-829.

Holz, M. 2015. Mesozoic paleogeography and paleoclimates: a discussion of the diverse greenhouse and hothouse conditions of an alien world. Journal of South American Earth Sciences 61, 91-107.

Hornung, T., Brandner, R. 2005. Biostratigraphy of the Reingraben Turnover (Hallstatt Facies Belt): local black shale events controlled by the regional tectonics, climatic change and plate tectonics. Facies 51, 460-479.

Hornung, T., Brandner, R., Krystyn, L., Joachimski, M.M., Keim, L. 2007a. Multistratigraphic constraints on the NW Tethyan "Carnian crisis". In: Lucas, S.G. and Spielmann, J.A. (Eds), The Global Triassic. New Mexico Museum of Natural History and Science Bulletin 41, 59-67.

Hornung, T., Krystyn, L., Brandner, R. 2007b. A Tethys-wide mid-Carnian (Upper Triassic) carbonate productivity decline: evidence for the Alpine Reingraben Event from Spiti (Indian Himalaya)? Journal of Asian Earth Sciences 30, 285-302.

Ivanov, Ž. 1998. Tectonics of Bulgaria. Professorship Thesis. Sofia University "St. Kliment Ohridski”, 634 pp. (in Bulgarian).

Jaglarz, P. 2010. Facies and sedimentary environment of the carbonate-dominated Carpathian Keuper from the Tatri- cum domain: results from the Dolina Smytnia Valley (Tatra Mts., Southern Poland). Annales Societatis Geologorum Poloniae 80, 147-161.

Johnsson, M.J. 1990. Tectonic versus chemical-weathering controls on the composition of fluvial sands in tropical environments. Sedimentology 37, 713-726.

Johnsson, M.J., Stallard, R.F., Meade, R.H. 1988. First-cycle quartz arenites in the Orinoco River Basin, Venezuela and Colombia. Journal of Geology 96, 263-277.

Khalifa, M.A. 2017. General characteristics of quartz arenite types and their role in the recognition of sequence stratigraphic boundaries in ancient coastal and near shore sediments: a case study from Egypt and Saudi Arabia. Journal of African Earth Sciences 130, 274-292.

Kolar-Jurkovsek, T., Jurkovsek, B. 2010. New paleontological evidence of the Carnian strata in the Mežica area (Karavanke Mts, Slovenia): conodont data for the Carnian pluvial event. Palaeogeography, Palaeoclimatology, Palaeoecology 290, 81-88.

Kovács, S., Sudar, M., Grădinaru, E., Gawlick, H.-J., Karamata, S., Haas, J., Péró, C., Gaetani, M., Mello, J., Polák, M., Aljinović, D., Ogorelec, B., Kolar-Jurkovšek, T., Jurkovšek, B., Buser, S. 2011. Triassic evolution of the tectonostratigraphic units of the Circum-Pannonian Region. Jahrbuch der Geologischen Bundesanstalt 151, 199-280.

Kozur, H.W., Bachmann, G.H. 2010. The Middle Carnian Wet Intermezzo of the Stuttgart Formation (Schilfsandstein), Germanic Basin. Palaeogeography, Palaeoclimatology, Palaeoecology 290, 107-119.

Lahtinen, R., Nironen, M. 2010. Paleoproterozoic lateritic paleosol-ultra-mature/mature quartzite-metaarkose successions in southern Fennoscandia: intra-orogenic stage during the Svecofennian orogeny. Precambrian Research $183,770-790$.

Lindsey, D.A. 1999. An evaluation of alternative chemical classifications of sandstones. Open-File Report 99-346, electronic edition, U.S. Geological Survey (https://pubs. usgs.gov/of/1999/0346/report.pdf).

Lintnerová, O., Michalík, J., Uhlík, P., Soták, J., Weissová, Z. 2013. Latest Triassic climate humidification and kaolinite formation (Western Carpathians, Tatric Unit of the Tatra Mts.). Geological Quarterly 57, 701-728.

Longiaru, S. 1987. Dual comparators for estimating the degree of sorting from plane and thin section. Journal of Sedimentary Petrology 57, 791-794.

Ludvigson, G.A., González, L.A., Fowle, D.A., Roberts, J.A., Driese, S.G., Villarreal, M.A., Smith, J.J., Suarez, M.B. 2013. Paleoclimatic applications and modern process studies of pedogenic siderite. In: Driese, S.G., Nordt, L.C., McCarthy, P.J. (Eds), New frontiers in paleopedology and terrestrial paleoclimatology. Society of Economic Paleontologists and Mineralogists, Special Publication 104, 79-87.

Lukeneder, S., Lukeneder, A., Harzhauser, M., İslamoğlu, Y., Krystyn, L., Lein, R.A. 2012. Delayed carbonate factory breakdown during the Tethyan-wide Carnian pluvial episode along the Cimmerian terranes (Taurus, Turkey). Facies 58, 279-296.

Mader, D., Čatalov, G. 1992. Milanovo Plateau, Teteven Anticlinorium, Trojan Balkan and Meljane Anticline (Bulgaria): Keuper-facies. In: Mader, D. (Ed.), Evolution of paleoecology and paleoenvironment of Permian and Triassic fluvial basins in Europe. Vol. 2 - Southeastern Europe. Gustav Fischer, Stuttgart-New York, 1079-1140.

Mader, N.K., Redfern, J., El Ouataoui, M. 2017. Sedimentology of the Essaouira Basin (Meskala Field) in context of regional sediment distribution patterns during upper Triassic pluvial events. Journal of African Earth Sciences 130, 293-318. 
Marcoux, J., Baud, A., Ricou, L.E., Bellion, Y., Besse, J., Gaetani, M., Gallet, Y., Guirard, R., Krystyn, L., Moreau, C., Theveniaut, H. 1993. Late Anisian palaeoenvironments (237-234 Ma). In: Dercourt, J., Ricou, L.E., Vrielynck, B. (Eds), Atlas Tethys Palaeoenvironmental Maps. BEICIPFRANLAB, Rueil-Malmaison.

McBride, E.F. 1987. Diagenesis of the Maxon Sandstone (Early Cretaceous), Marathon region, Texas: a diagenetic quartzarenite. Journal of Sedimentary Petrology 57, 98-107.

McKie, T. 2014. Climatic and tectonic controls on Triassic dryland terminal fluvial system architecture, central North Sea. In: Martinius, A.W., Ravnås, R., Howell, J.A., Steel, R.J., Wonham, J.P. (Eds), From depositional systems to sedimentary successions on the Norwegian continental margin. International Association of Sedimentologists, Special Publication 46, 19-58.

Mueller, S., Hounslow, M.W., Kürschner, W.M. 2016a. Integrated stratigraphy and palaeoclimate history of the Carnian Pluvial Event in the Boreal realm: new data from the Upper Triassic Kapp Toscana Group in central Spitsbergen (Norway). Journal of the Geological Society 173, 186-202.

Mueller, S., Krystyn, L., Kürschner, W.M. 2016b. Climate variability during the Carnian Pluvial Phase - a quantitative palynological study of the Carnian sedimentary succession at Lunz am See, Northern Calcareous Alps, Austria. Palaeogeography, Palaeoclimatology, Palaeoecology 441, 198-211.

Mutti, M., Weissert, H. 1995. Triassic monsoonal climate and its signature in Ladinian-Carnian carbonate platforms (Southern Alps, Italy). Journal of Sedimentary Research 65B, 357-367.

Muttoni, G., Gaetani, M., Budurov, K., Zagorchev, I., Trifonova, E., Ivanova, D., Petrunova, L., Lowrie, W. 2000. Middle Triassic paleomagnetic data from northern Bulgaria: constraints on Tethyan magnetostratigraphy and paleogeography. Palaeogeography, Palaeoclimatology, Palaeoecology 160, 223-237.

Nakada, R., Ogawa, K., Suzuki, N., Takahashi, S., Takahashi, Y. 2014. Late Triassic compositional changes of aeolian dusts in the pelagic Panthalassa: response to the continental climatic change. Palaeogeography, Palaeoclimatology, Palaeoecology 393, 61-75.

Nowrouzi, Z., Moussavi-Harami, R., Mahboubi, A., Mahmudy Gharaie, M.H., Ghaemi, F. 2014. Petrography and geochemistry of Silurian Niur Sandstones, Derenjal Moubtains, East Central Iran: implications for tectonic setting, provenance and weathering. Arabian Journal of Geoscience 7, 2793-2813.

Ortí, F., Pérez-López, A., Salvany, J.M. 2017. Triassic evaporites of Iberia: sedimentological and palaeogeographical implications for the western Neotethys evolution during the Middle Triassic-Earliest Jurassic. Palaeogeography, Palaeoclimatology, Palaeoecology 471, 157-180.

Paraschiv, D. 1982. The principal lithostratigraphic units in the pre-Jurassic of the Moesian Platform. Mine, Petrol and Gaze 33, 134-136 (in Romanian).

Parrish, J.T. 1998. Interpreting pre-Quaternary climate from the geological record. Columbia University Press, New York, $338 \mathrm{pp}$.

Pettijohn, F.J. 1975. Sedimentary rocks (3 ${ }^{\text {rd }}$ ed.). Harper, New York, $628 \mathrm{pp}$.

Pettijohn, F.J., Potter, P.E., Siever, R. 1972. Sand and sandstone. Springer, New York, $618 \mathrm{pp}$.

Powers, M.C. 1953. A new roundness scale for sedimentary particles. Journal of Sedimentary Petrology 23, 117-119.

Preto, N., Kustatscher, E., Wignall, P.B. 2010. Triassic climates - state of the art and perspectives. Palaeogeography, Palaeoclimatology, Palaeoecology 290, 1-10.
Prochnow, S.J., Nordt, L.C., Atchley, S.C., Hudec, M.R. 2006. Multi-proxy paleosol evidence for Middle and Late Triassic climate trends in eastern Utah. Palaeogeography, Palaeoclimatology, Palaeoecology 232, 53-72.

Quan, C., Liu, Z., Utescher, T., Jin, J., Shu, J., Li, Y., Liu, Y.-S. 2014. Revisiting the Paleogene climate pattern of East Asia: a synthetic review. Earth-Science Reviews 139, 213-230.

Rigo, M., Preto, N., Roghi, G., Tateo, F., Mietto, P. 2007. A rise in the carbonate compensation depth of western Tethys in the Carnian (Late Triassic): deep-water evidence for the Carnian Pluvial Event. Palaeogeography, Palaeoclimatology, Palaeoecology 246, 188-205.

Roghi, G., Gianolla, P., Minarelli, L., Pilati, C., Preto, N. 2010. Palynological correlation of Carnian humid pulses throughout western Tethys. Palaeogeography, Palaeoclimatology, Palaeoecology 290, 89-106.

Rostasi, A., Raucsik, B., Varga, A. 2011. Palaeoenvironmental controls on the clay mineralogy of Carnian sections from the Transdanubian Range (Hungary). Palaeogeography, Palaeoclimatology, Palaeoecology 300, 101-112.

Roy, D.K., Roser, B.P. 2013. Climatic control on the composition of Carboniferous-Permian Gondwana sediments, Khalaspir basin, Bangladesh. Gondwana Research 23, 1163-1171.

Ruffell, A., Simms, M.J., Wignall, P.B. 2016. The Carnian humid episode of the late Triassic: a review. Geological Magazine 153, 271-284.

Schneider, S., Hornung, J., Hinderer, M., Garzanti, E. 2016. Petrography and geochemistry of modern river sediments in an equatorial environment (Rwenzori Mountains and Albertine rift, Uganda): implications for weathering and provenance. Sedimentary Geology 336, 106-119.

Sellwood, B.W., Price, G.D. 1993. Sedimentary facies as indicators of Mesozoic palaeoclimate. Philosophical Transactions of the Royal Society of London, Series B 341, $225-233$.

Simms, M.J., Ruffell, A.H. 1989. Synchroneity of climatic change in the late Triassic. Geology 17, 265-268.

Simms, M.J., Ruffell, A.H., Johnson, L.A. 1995. Biotic and climatic changes in the Carnian (Triassic) of Europe and adjacent areas. In: Fraser, N.C., Sues, H.D. (Eds), In the shadow of the dinosaurs. Early Mesozoic tetrapods. Cambridge University Press, Cambridge, 352-365.

Smyth, H.R., Hall, R., Nichols, G.J. 2008. Significant volcanic contribution to some quartz-rich sandstones, East Java, Indonesia. Journal of Sedimentary Research 78, 335-356.

Spencer, J.E., Pecha, M.E., Gehrels, G.E., Dickinson, W.R., Domanik, K.J., Quade, J. 2016. Paleoproterozoic orogenesis and quartz-arenite deposition in the Little Chino Valley area, Yavapai tectonic province, central Arizona, USA. Geosphere 12, 1774-1794.

Stefani, M., Furin, S., Gianolla, P. 2010. The changing climate framework and depositional dynamics of Triassic carbonate platforms from the Dolomites. Palaeogeography, Palaeoclimatology, Palaeoecology 290, 43-57.

Sun, Y., Joachimski, M.M., Wignall, P.B., Yan, C., Chen, Y., Jiang, H., Wang, L., Lai, X. 2012. Lethally hot temperatures during the early Triassic greenhouse. Science 338, 366-370.

Sun, X.L., Wignall, P.B., Joachimski, M.M., Bond, D.P.G., Grasby, S.E., Lai, X.L., Wang, L.N., Zhang, Z.T., Sun, S. 2016. Climate warming, euxinia and carbon isotope perturbations during the Carnian (Triassic) crisis in South China. Earth and Planetary Science Letters 444, 88-100.

Suttner, L.J., Basu, A., Mack, G.H. 1981. Climate and the origin of quartzarenite. Journal of Sedimentary Petrology 51, $1235-1246$. 
Suttner, L.J., Dutta, P.K. 1986. Alluvial sandstone composition and palaeoclimate, I. Framework mineralogy. Journal of Sedimentary Petrology 56, 329-345.

Sýkora, M., Siblík, M., Soták, J. 2011. Siliciclastics in the Upper Triassic dolomite formations of the Krížna Unit (Malá Fatra Mountains, Western Carpathians): constraints for the Carnian Pluvial Event in the Fatric Basin. Geologica Carpathica $62,121-138$.

Tanner, L.H., Khalifa, M.A. 2010. Origin of ferricretes in fluvial-marine deposits of the Lower Cenomanian Bahariya Formation, Bahariya Oasis, Western Desert, Egypt. Journal of African Earth Sciences 56, 179-189.

Tronkov, D. 1960. On the Triassic stratigraphy of the Iskar River gorge. Annuaire de la Direction générale des recherches géologiques, série A 10,131-153 (in Bulgarian, with German abstract).

Tronkov, D. 1963. Character of the Old Cimmerian structural stage ockwerkbaus, type and age of the Old Cimmerian tectonic movements in Northwestern Bulgaria. Travaux sur la Géologie de Bulgarie, Série Stratigraphie et Tectonique 5, 171-196 (in Bulgarian, with Russian and German abstracts).

Tronkov, D. 1969. Neue Angaben über das Alter der bunten Gesteine des "Räts" (obere Trias) in Bulgarien. Comptes rendus de l'Académie bulgare des Sciences 22, 1169-1172.

Tronkov, D. 1973. Grounding in the Triassic stratigraphy of the Belogradchik Anticlinorium (Northwestern Bulgaria). Bulletin of the Geological Institute, Series Stratigraphy and Lithology 22, 73-98 (in Bulgarian, with Russian and German abstracts).

Tronkov, D. 1995a. Triassic system. In: Haydutov, I. (Ed.), Explanatory note to the Geological map of Bulgaria. Scale 1:100 000. Belogradčik map sheet. Geology and Mineral Resources Committee, Enterprise of Geophysical Survey and Geological Mapping, Sofia, 49-68 (in Bulgarian, with English abstract).

Tronkov, D. 1995b. Triassic system. In: Haydutov, I. (Ed.), Explanatory note to the Geological map of Bulgaria. Scale 1:100 000. Berkovitsa map sheet. Geology and Mineral Resources Committee, Enterprise of Geophysical Survey and Geological Mapping, Sofia, 44-59 (in Bulgarian, with English abstract).

Tronkov, D., Encheva, M., Trifonova, E. 1965. Stratigraphy of the Triassic System in Northwestern Bulgaria. Bulletin of the "Strašimir Dimitrov" Institute of Geology 14, 261-292 (in Bulgarian, with German abstract).

Tronkov, D., Monov, B. 1971. Triassic stratigraphy based on data from wells near the villages Beli izvor and Glavatsi, Vratsa district. Bulletin of the Geological Institute, Series Stratigraphy and Lithology 20, 15-32 (in Bulgarian, with Russian and German abstracts).
Trotter, J.A., Williams, I.S., Nicora, A., Mazza, M., Rigo, M. 2015. Long-term cycles of Triassic climate change: a new $\delta^{18} \mathrm{O}$ record from conodont apatite. Earth and Planetary Science Letters 415, 165-174.

Urošević, D., Radulović, V. 1990. The uppermost RhaetianLower Liassic continental terrigenous Senokos Formation in the Yugoslavian Carpatho-Balkanides (Stara Planina Mt.). Geologisch-Paläontologische Mitteilung Innsbruck 17, 25-30.Van de Kamp, P.C. 2010. Arkose, subarkose, quartz sand, and associated muds derived from felsic plutonic rocks in glacial to tropical humid climates. Journal of Sedimentary Petrology 80, 895-918.

van Hattum, M.W.A., Hall, R., Pickard, A.L., Nichols, G.J. 2006. SE Asian sediments not from Asia: provenance and geochronology of North Borneo sandstones. Geology 34, 589-592.

Vaptsarova, A., Chemberski, H. 1984. Le Trias dans la Bulgarie du Nord. V. Lithologie des sédiments bigarres du Trias supérieur (Groupe Moésien). Geologica Balcanica 14, 47-70.

Vaptsarova, A., Chemberski, H., Chatalov, G. 1984. Facies and evolution of sedimentary environments during the Triassic period in Bulgaria. Geologica Balcanica 14, 57-76 (in Russian, with English abstract).

Velde, B., Meunier, A. 2008. The origin of clay minerals in soils and weathered rocks. Springer, Berlin-Heidelberg, $406 \mathrm{pp}$.

Weltje, G.J. 1994. Provenance and dispersal of sand-sized sediments: reconstruction of dispersal patterns and sources of sand-sized sediments by means of inverse modelling techniques. Geologica Ultraiectina 121, 1-208.

Went, D.J. 2013. Quartzite development in early Palaeozoic nearshore marine environments. Sedimentology 60, 10361058.

Widdowson, M. 2007. Laterite and ferricrete. In: Nash, D.J., McLaren, S.J. (Eds), Geochemical sediments and landscapes. Blackwell, Malden, 46-94.

Xu, G., Hannah, J.L., Stein, H.J., Mørk, A., Vigran, J.O., Bingen, B., Schutt, D.L., Lundschein, B.A. 2014. Cause of Upper Triassic climate crisis revealed by Re-Os geochemistry of Boreal black shales. Palaeogeography, Palaeoclimatology, Palaeoecology 395, 222-232.

Young, G.M. 2013. Secular changes at the Earth"s surface; evidence from palaeosols, some sedimentary rocks, and palaeoclimatic perturbations of the Proterozoic Eon. Gondwana Research 24, 453-467.

Young, S.W. 1976. Petrographic textures of detrital polycrystalline quartz as an aid to interpreting crystalline source rocks. Journal of Sedimentary Petrology 46, 595-603.

Zagorchev, I., Budurov, K. 2007. Stratigraphic problems of the Moesian Group (Upper Triassic, peri-Tethyan type), Bulgaria. Geologica Balcanica 36, 31-53. 